\title{
Quantification of the unknown HONO daytime source and its relation to $\mathrm{NO}_{2}$
}

\author{
M. Sörgel ${ }^{1,2}$, E. Regelin ${ }^{3}$, H. Bozem ${ }^{3, *}$, J.-M. Diesch ${ }^{4}$, F. Drewnick ${ }^{4}$, H. Fischer ${ }^{3}$, H. Harder ${ }^{3}$, A. Held ${ }^{2}$, \\ Z. Hosaynali-Beygi ${ }^{3}$, M. Martinez ${ }^{3}$, and C. Zetzsch ${ }^{1,5}$ \\ ${ }^{1}$ University of Bayreuth, Atmospheric Chemistry Research Laboratory, Bayreuth, Germany \\ ${ }^{2}$ University of Bayreuth, Junior Professorship in Atmospheric Chemistry, Bayreuth, Germany \\ ${ }^{3}$ Max Planck Institute for Chemistry, Atmospheric Chemistry Department, P.O. Box 3060, 55020 Mainz, Germany \\ ${ }^{4}$ Max Planck Institute for Chemistry, Particle Chemistry Department, P.O. Box 3060, 55020 Mainz, Germany \\ ${ }^{5}$ Fraunhofer Institute for Toxicology and Experimental Medicine, Hannover, Germany \\ * now at: University Mainz, Institute for Atmospheric Physics, Mainz, Germany
}

Received: 1 April 2011 - Published in Atmos. Chem. Phys. Discuss.: 18 May 2011

Revised: 29 September 2011 - Accepted: 8 October 2011 - Published: 20 October 2011

\begin{abstract}
During the DOMINO (Diel Oxidant Mechanism In relation to Nitrogen Oxides) campaign in southwest Spain we measured simultaneously all quantities necessary to calculate a photostationary state for HONO in the gas phase. These quantities comprise the concentrations of $\mathrm{OH}, \mathrm{NO}$, and $\mathrm{HONO}$ and the photolysis frequency of $\mathrm{NO}_{2}, j\left(\mathrm{NO}_{2}\right)$ as a proxy for $j(\mathrm{HONO})$. This allowed us to calculate values of the unknown HONO daytime source. This unknown HONO source, normalized by $\mathrm{NO}_{2}$ mixing ratios and expressed as a conversion frequency $\left(\% \mathrm{~h}^{-1}\right)$, showed a clear dependence on $j\left(\mathrm{NO}_{2}\right)$ with values up to $43 \% \mathrm{~h}^{-1}$ at noon. We compared our unknown HONO source with values calculated from the measured field data for two recently proposed processes, the light-induced $\mathrm{NO}_{2}$ conversion on soot surfaces and the reaction of electronically excited $\mathrm{NO}_{2} *$ with water vapour, with the result that these two reactions normally contributed less than $10 \%\left(<1 \% \mathrm{NO}_{2}+\right.$ soot $+h v$; and $\left.<10 \% \mathrm{NO}_{2} *+\mathrm{H}_{2} \mathrm{O}\right)$ to our unknown $\mathrm{HONO}$ daytime source. $\mathrm{OH}$ production from HONO photolysis was found to be larger (by $20 \%$ ) than the "classical" OH formation from ozone photolysis $\left(\mathrm{O}\left({ }^{1} \mathrm{D}\right)\right)$ integrated over the day.
\end{abstract}

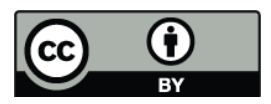

Correspondence to: $\mathrm{M}$. Sörgel (matthias.soergel@uni-bayreuth.de)

\section{Introduction}

Nitrous acid (HONO) is an important $\mathrm{OH}$ radical precursor which serves as the "detergent" of the atmosphere due to its oxidizing power. Besides its importance for the atmospheric oxidation potential, HONO is part of acid and nutrient deposition to the biosphere. Moreover, growing concern exists about possible health effects due to the formation of nitrosamines (Hanst et al., 1977; Pitts et al., 1978) where HONO acts as the nitrosating agent, especially in indoor environments after wall reactions of HONO with nicotine (Sleiman et al., 2010). Despite three decades of research since the first unequivocal detection of HONO in the atmosphere (Perner and Platt, 1979), HONO formation processes in the atmosphere are still under discussion, especially during daytime where large discrepancies were found between mixing ratios calculated from known gas phase chemistry and measured daytime mixing ratios (Kleffmann et al., 2005). In the absence of light, the most favoured formation reaction is the heterogeneous disproportionation of nitrogen dioxide $\left(\mathrm{NO}_{2}\right)$ :

$2 \mathrm{NO}_{2}+\mathrm{H}_{2} \mathrm{O} \rightarrow \mathrm{HONO}+\mathrm{HNO}_{3}$

This reaction has been extensively studied on different materials like fluorinated polymers and different types of glass as reviewed by Lammel and Cape (1996), but also on building materials like concrete (Trick, 2004). It was found to be first order in $\mathrm{NO}_{2}$ and water vapour (Sakamaki et al., 1983; Svennson et al., 1987; Pitts et al., 1984; Jenkin et al., 1988). A mechanism involving the formation of the $\mathrm{NO}_{2}$

Published by Copernicus Publications on behalf of the European Geosciences Union. 
dimer $\left(\mathrm{N}_{2} \mathrm{O}_{4}\right)$ in the gas phase was proposed (Finlayson-Pitts et al., 2003), but is not important in the real atmosphere (K1effmann et al., 1998; Gustafsson et al., 2008). Recently, evidence for a mechanism involving reaction between adsorbed $\mathrm{NO}_{2}$ and $\mathrm{H}\left(\mathrm{NO}_{2}\right.$ (ads) $+\mathrm{H}(\mathrm{ads}) \rightarrow \mathrm{HONO}$ (ads)) present on the surface following the dissociation of chemisorbed $\mathrm{H}_{2} \mathrm{O}$ was found in a study on mineral dust particles with isotopically labelled water (Gustafsson et al., 2008), but the results are probably not transferable from laboratory to field conditions (Finlayson-Pitts, 2009). The disproportionation Reaction (R1) was found to be catalysed by anions at the surface of droplets (Yabushita et al., 2009; Kinugawa et al., 2011). In the absence of light, $\mathrm{HONO}$ formation from $\mathrm{NO}_{2}$ on soot deactivates quite rapidly and thus was concluded to be less important for atmospheric HONO formation except for freshly emitted soot (Kleffmann et al., 1999; Arens et al., 2001; Aubin and Abbatt, 2007). The mechanism was summarized as the Reaction (R2) of reducing organic compounds $\{\mathrm{C}-\mathrm{H}\}_{\text {red }}$ with $\mathrm{NO}_{2}$ (Gutzwiller et al., 2002a). A reaction similar to Reaction (R2) was postulated for the aqueous phase (Gutzwiller et al., 2002b; Ammann et al., 2005), but only proceeds at a relevant rate at high $\mathrm{pH}$ levels, since it is based on the well-known charge transfer reaction of phenolate with $\mathrm{NO}_{2}$.

$\mathrm{NO}_{2}+\{\mathrm{C}-\mathrm{H}\}_{\mathrm{red}} \rightarrow \mathrm{HONO}+\{\mathrm{C}\}_{\mathrm{ox}}$

$\mathrm{NO}+\mathrm{NO}_{2}+\mathrm{H}_{2} \mathrm{O} \rightarrow 2 \mathrm{HONO}$

$\mathrm{HNO}_{3}($ ads $)+\mathrm{NO}(\mathrm{g}) \rightarrow \mathrm{HONO}+\mathrm{NO}_{2}$

The Reactions (R3) (via the intermediate $\mathrm{N}_{2} \mathrm{O}_{3}$ ) and (R4) proposed from field measurements (Calvert et al., 1994; Andres-Hernandez et al., 1996; Saliba et al., 2001) could neither explain laboratory results under low $\mathrm{NO}_{\mathrm{x}}$ conditions (Svensson et al., 1987; Jenkin et al., 1988; Kleffmann et al., 1998, 2004) nor field experiments with low NO mixing ratios (Harrison and Kitto, 1994; Alicke et al., 2003; this study).

During daytime the dominant sink for HONO is photolysis according to Reaction (R5), which forms $\mathrm{OH}$.

$\mathrm{HONO}+\mathrm{h} v \rightarrow \mathrm{NO}+\mathrm{OH}$

An additional sink is the reaction of $\mathrm{HONO}$ with $\mathrm{OH}$ (R6).

$\mathrm{HONO}+\mathrm{OH} \rightarrow \mathrm{NO}_{2}+\mathrm{H}_{2} \mathrm{O}$

The back reaction (R7) regenerates HONO.

$\mathrm{NO}+\mathrm{OH}+\mathrm{M} \rightarrow \mathrm{HONO}+\mathrm{M}$

At high insolation, Reactions (R5-R7) are supposed to be in a photostationary state (PSS) (Cox, 1974; Kleffmann et al., 2005). Only few studies (Kleffmann et al., 2005; Acker et al., 2006) measured all quantities necessary to calculate the photostationary state (no net $\mathrm{OH}$ formation), some with $j$ (HONO) calculated from UV measurements (Ren et al.,
2003, 2006). In all these studies measured HONO values exceeded the HONO values calculated from PSS. The "dark" heterogeneous formation (via Reactions (R1)/(R2)) was too slow (20-60 times) to explain this discrepancy (Kleffmann et al., 2003, 2005). This stimulated laboratory studies about a light-induced conversion of $\mathrm{NO}_{2}$ to HONO or other photolytic sources of HONO as recently summarized by Kleffmann (2007). There are a variety of proposed sources dealing with light-induced $\mathrm{NO}_{2}$ reduction including $\mathrm{NO}_{2}$ reduction on irradiated mineral surfaces like $\mathrm{TiO}_{2}$ (Gustafsson et al., 2006; Ndour et al., 2008). Many studies focussed on the reduction of $\mathrm{NO}_{2}$ involving organic photosensitizers (George et al., 2005) like hydrocarbons on soot (Monge et al., 2010) or humic acids (Stemmler et al., 2006, 2007).

As already proposed from smog chamber experiments (Killus and Whitten, 1990), photolysis of deposited $\mathrm{HNO}_{3} /$ nitrate on surfaces was suggested as a daytime HONO source for rural forested environments by Zhou et al. (2002a, b, 2003) and Raivonnen et al. (2006). This mechanism is still controversial since the photolysis of $\mathrm{HNO}_{3}$ was not found to be a photolytic source of HONO in chamber experiments (Rohrer et al., 2005), and quantum yields for $\mathrm{HNO}_{3} /$ nitrate photolysis are too low in the gas phase and in solution (Kleffmann, 2007). The photolysis of $\mathrm{HNO}_{3}$ might be enhanced at surfaces (Finlayson-Pitts, 2009) or via organic photosensitizers as speculated by Kleffmann (2007). Recent studies showed the enhanced light absorption of surface adsorbed $\mathrm{HNO}_{3}$ compared to the gas phase (Zhu et al., 2008, 2010), and thus higher photolysis rates of adsorbed $\mathrm{HNO}_{3}$. These laboratory studies identified $\mathrm{NO}_{2} *$ as the main photolysis product. Zhou et al. (2011), who found that their HONO daytime source is correlated to the product of surface nitrate loading and the photolysis frequency of $\mathrm{HNO}_{3}$, concluded that HONO formation by $\mathrm{HNO}_{3}$ photolysis at the surface occurs via the mechanism proposed by Stemmler et al. (2006).

A direct HONO source is the photolysis of nitrophenols (Bejan et al., 2006) depending on pollution levels which govern the formation of nitrophenols.

The contribution of the reaction of electronically excited $\mathrm{NO}_{2} *$ with water vapour (R8) to the oxidation capacity of the troposphere was investigated in recent modelling studies (Wennberg and Dabdub, 2008; Sarwar et al., 2009; Ensberg et al., 2010). These studies focussed on ozone formation and concluded that there is an impact on oxidant formation for high $\mathrm{NO}_{\mathrm{x}}$ emissions when using the rate constant of $\mathrm{Li}$ et al. (2008) for reactive quenching of $\mathrm{NO}_{2} *$. Even with low $\mathrm{NO}_{\mathrm{x}}$ emissions the influence is still noticeable, whereas using the rate constant of Crowley and Carl (1997) the impact is negligible. The portion of the reactive quenching of $\mathrm{NO}_{2} *$ by $\mathrm{H}_{2} \mathrm{O}$ (and thus the rate constant of Reaction (R8), $k_{8}$ ) is still under discussion (Carr et al., 2009; Li et al., 2009; Fang et al., 2010; Blitz, 2010). In their laboratory study, Crowley and Carl (1997) did not observe any $\mathrm{OH}$ production via Reaction (R8) and thus derived an upper limit for the reactive quenching of 
$\mathrm{NO}_{2}^{*}$ by $\mathrm{H}_{2} \mathrm{O}$ of $k_{8}=1.2 \times 10^{-14} \mathrm{~cm}^{3}$ molecules ${ }^{-1} \mathrm{~s}^{-1}$. A recent study by Carr et al. (2009) confirmed these findings. In contrast to these studies which used unfocused laser beams, Li et al. (2008) observed $\mathrm{OH}$ production and report a one order of magnitude higher value for $k_{8}=1.7 \times$ $10^{-13} \mathrm{~cm}^{3}$ molecules ${ }^{-1} \mathrm{~s}^{-1}$.

$\mathrm{NO}_{2} *+\mathrm{H}_{2} \mathrm{O} \rightarrow \mathrm{HONO}+\mathrm{OH}$

In this study we quantify the gas phase photostationary state for HONO from measured values in Spain, calculate the values of the unknown HONO daytime source, and compare the latter with HONO formation from Reaction (R8) and the light-induced $\mathrm{NO}_{2}$ conversion on soot (Monge et al., 2010).

\section{Experimental}

The Diel Oxidant Mechanism In relation to Nitrogen Oxides (DOMINO) campaign took place at the "Atmospheric Sounding Station - El Arenosillo", a platform of the Atmospheric Research and Instrumentation Branch of the Spanish National Institute for Aerospace Technology (INTA) dedicated to atmospheric measurements in the southwest of Spain $\left(37^{\circ} 05^{\prime} 48.03^{\prime \prime} \mathrm{N}, 6^{\circ} 44^{\prime} 07.47^{\prime \prime} \mathrm{W}\right)$. The measurement site was about $300 \mathrm{~m}$ inland from the coast of the Atlantic Ocean in a large area of uniform pine (Pinus pinea L.) forest with sandy soil. Only sparse buildings and streets were located around the site. The average canopy height was about 6 $\mathrm{m}$. The leaf area index (LAI) for this forested area is about 11.5 (Gonçalves et al., 2010). About $15 \mathrm{~km}$ to the northwest is the industrial area of Huelva, with refineries and other heavy industry. The metropolitan area of Seville is about $70 \mathrm{~km}$ to the east-north-east. The campaign took place from mid November to mid December 2008.

Measurements of HONO were conducted at a height of $10 \mathrm{~m}$ above ground ( $\sim 4 \mathrm{~m}$ above canopy) on a scaffold and at $1 \mathrm{~m}$ above ground, by commercial LOPAP instruments (LOng Path Absorption Photometer, QUMA Elektronik \& Analytik, Wuppertal, Germany). The LOPAP is based on a wet chemical technique, with fast sampling of $\mathrm{HONO}$ as nitrite in a stripping coil and subsequent detection as an azo dye using long path absorption in $2.4 \mathrm{~m}$ long Teflon AF tubing. A detailed description of the instrument has been given by Heland et al. (2001) and Kleffmann et al. (2002). The instruments were placed outside directly on the scaffolds in ventilated aluminium boxes without temperature control. The temperature of the stripping coils was kept constant at $20^{\circ} \mathrm{C}$ by thermostats to assure constant sampling conditions. The overall relative error of the LOPAP instruments was found to be $12 \%$ in a recent side by side intercomparison in the field (Sörgel et al., 2011). Detection limits during DOMINO, calculated as $3 \sigma$ of the noise during zero air measurements, were between 1 and $2.5 \mathrm{ppt}$.
The instrument used to measure $\mathrm{NO}_{\mathrm{x}}$ was a high resolution and high sensitivity chemiluminescence detector (ECOPhysics CLD 790 SR, ECO-Physics, Dürnten, Switzerland) which carries out simultaneous in situ measurements of $\mathrm{NO}$ and $\mathrm{NO}_{2}$. $\mathrm{NO}$ is measured directly, however, $\mathrm{NO}_{2}$ is measured indirectly after conversion to NO using a blue light converter which is a solid state photolytic converter (Droplet Measurement Technologies, Boulder, Co, USA). A detailed description of the instrument, the calibration techniques and the error calculation has been given by Hosaynali-Beygi et al. (2011). Air was sampled through a polytetrafluoroethylene (PTFE) inlet line which was mounted on top of a scaffold at the measurement site at a height of $10 \mathrm{~m}$ above the ground. From there an inlet line which consisted of $1 / 2^{\prime \prime}$ PTFE tubing was installed to the container. The last meter of the inlet line consisted of $1 / 4^{\prime \prime}$ PTFE tubing. The total uncertainty for the original $1 \mathrm{~s}$ data (at $2 \sigma$ ) based on the calculations of precision and accuracy is $6.04 \mathrm{ppt}+5 \%$ of reading for $\mathrm{NO}$ and $8.29 \mathrm{ppt}+8 \%$ of reading for $\mathrm{NO}_{2}$ measurements. The residence time in the tubing was about $3 \mathrm{~s}$. The shift in the tubing due to the reaction of $\mathrm{NO}$ with $\mathrm{O}_{3}$ was thus less than $5 \%$ for $\mathrm{NO}$ and less than $2 \%$ for $\mathrm{NO}_{2}$ during the campaign.

OH was measured by Laser Induced Fluorescence (LIF) with the "HORUS" (HydrOxyl Radical measurement Unit based on fluorescence Spectroscopy) instrument (Martinez et al., 2010). The detection system was placed next to the LOPAP on top of the scaffold $(10 \mathrm{~m})$. The measurement uncertainty was $\pm 18 \%$. Measured $\mathrm{OH}$ values present an upper limit due to interferences which can be up to a factor of two for some conditions (H. Harder, personal communication, 2011). The inlets for $\mathrm{HONO}, \mathrm{NO}_{\mathrm{x}}$ and $\mathrm{HO}_{\mathrm{x}}$ measurements were collocated at $10 \mathrm{~m}$ above ground on the scaffold.

$\mathrm{NO}_{2}$ photolysis frequencies $j\left(\mathrm{NO}_{2}\right)$ were measured by filter radiometers (Meteorologie consult, Königstein, Germany) on top of the scaffold, with an uncertainty of $\pm 5 \%$. The HONO photolysis frequency $(j(\mathrm{HONO}))$ was calculated by multiplying $j\left(\mathrm{NO}_{2}\right)$ with a factor of 0.175 (Trebs et al., 2009). By comparing different parameterizations (Kraus and Hofzumahaus, 1998; Trebs et al., 2009), the uncertainty for the calculation of $j(\mathrm{HONO})$ was estimated to be $5 \%$. The overall $(4 \pi)$ photolysis frequency was calculated by increasing values of the downwelling radiation by $5 \%$, i.e. the portion of the upwelling radiation (albedo of UV radiation) at this site (Cancillo et al., 2005).

Photolysis frequencies for $\mathrm{O}\left({ }^{1} \mathrm{D}\right)$ formation $\left(j\left(\mathrm{O}\left({ }^{1} \mathrm{D}\right)\right)\right.$ were calculated using the TUV model (Version 4.1, e.g. Madronich et al., 1998) taking the ozone column from the NASA webpage (http://jwocky.gsfc.nasa.gov/teacher/ozone_ overhead.html). We firstly derived a factor for scaling modelled $j\left(\mathrm{NO}_{2}\right)$ to measured $j\left(\mathrm{NO}_{2}\right)$. This factor was then applied for scaling modelled $j\left(\mathrm{O}^{1} \mathrm{D}\right)$.

Meteorological parameters like temperature, relative humidity $(\mathrm{RH})$, atmospheric pressure, wind speed and wind direction were measured with a Vaisala WXT510 (Vaisala, 


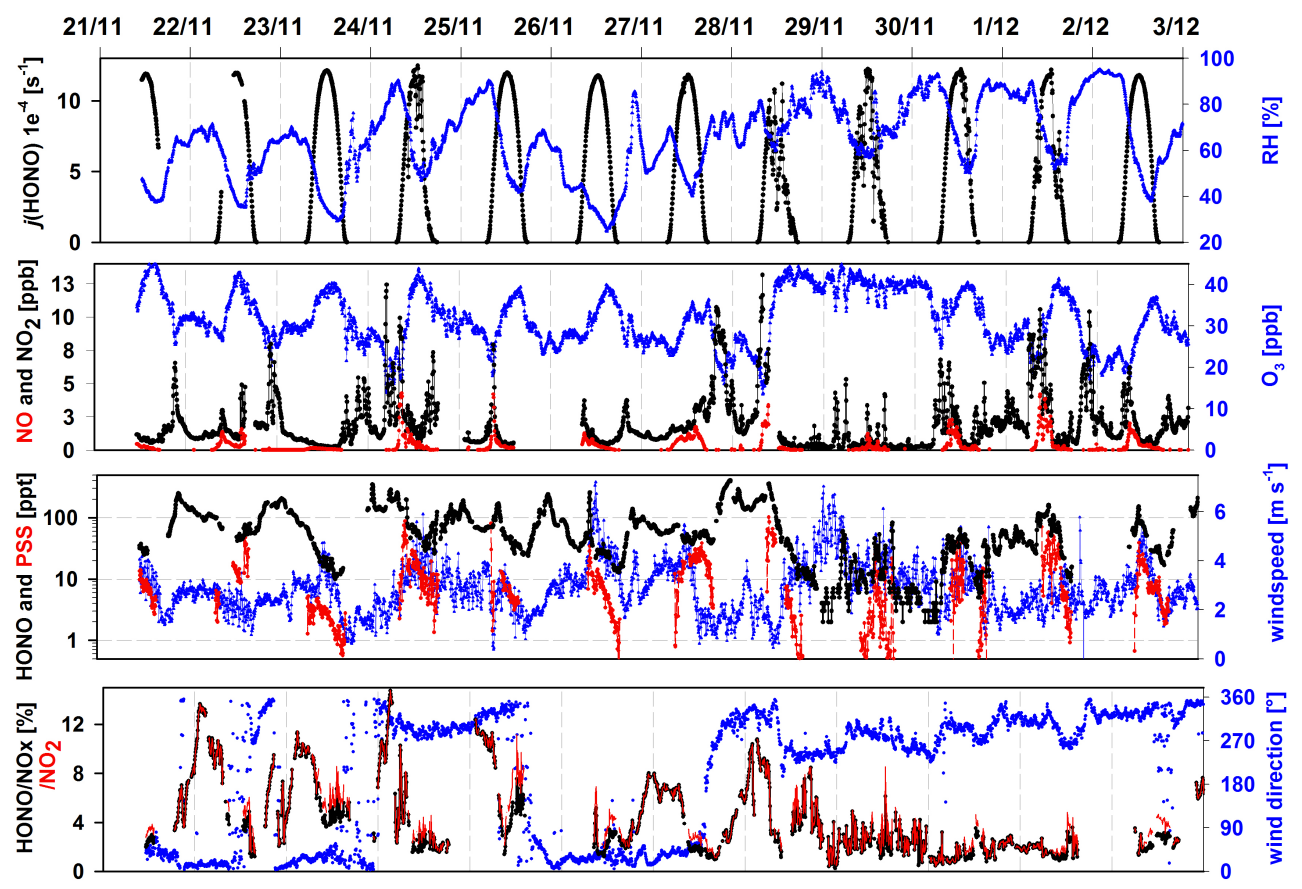

Fig. 1. Overview of meteorological $\left(\mathrm{RH}\right.$, wind speed and wind direction) and chemical quantities $\left(\mathrm{O}_{3}, \mathrm{NO}, \mathrm{NO}_{2}, \mathrm{HONO} \mathrm{HONO} \mathrm{PSS}\right.$ (calculated), $\mathrm{HONO} / \mathrm{NO}_{\mathrm{x}}$ and $\mathrm{HONO} / \mathrm{NO}_{2}$ ratios and $j(\mathrm{HONO})$ ).

Helsinki, Finnland) meteorological station on top of the MoLa (Mobile Laboratory) inlet system, which was at $10 \mathrm{~m}$ height $10 \mathrm{~m}$ southeast of the scaffold. For details see Diesch et al. (2011).

MoLa measured ozone by UV absorption with the "Airpointer" (Recordum, Mödling, Austria), water vapour mixing ratios by infrared absorption (LICOR 840, Li-COR, Lincol, USA) and black carbon with a Multi Angle Absorption Photometer (MAAP, Model 5012, Thermo Fischer Scientific, Whatman, USA).

\section{Results and discussion}

\subsection{Meteorological and chemical conditions}

Figure 1 gives an overview of meteorological and chemical measurements during the experiment in November/December 2008. In the beginning of the campaign there was a fair weather period with moderate (about $3 \mathrm{~m} \mathrm{~s}^{-1}$ ) north-easterly winds (from inland Seville region). On 24 November, the wind direction changed to northwest (along the coast from Huelva). From the 28 to 30 November, clean marine air with some plumes arrived at the site from the west. This was also the only period with rainfall, and HONO values were often around the detection limit (2ppt). Ozone mixing ratios were about $30 \mathrm{ppb}$ and showed a diurnal variation except for the clean air period with higher values $(40 \mathrm{ppb})$ and no diurnal variation. A more detailed analysis of the ozone behaviour and the different wind sectors has been given by Diesch et al. (2011).

\subsection{Photostationary state (PSS)}

\subsubsection{Calculating the photostationary state/gas phase}

Regarding only the well-established gas phase formation (R7) and gas phase sink processes (R5 and R6) one can calculate the photostationary state (PSS) mixing ratio of HONO (Cox, 1974; Kleffmann et al., 2005),

$\left[\mathrm{HONO}_{\mathrm{PSS}}\right]=\frac{k_{7}[\mathrm{NO}][\mathrm{OH}]}{k_{6}[\mathrm{OH}]+j(\mathrm{HONO})}$

[HONOPSS] is the equilibrium concentration, $[\mathrm{NO}]$ and $[\mathrm{OH}]$ are the measured $\mathrm{NO}$ and $\mathrm{OH}$ concentrations, and $j$ (HONO) is the photolysis frequency of HONO. Rate constants for the termolecular Reaction (R7) were calculated at atmospheric pressure from the fall-off curves (high and low pressure limit rate constants) according to the formulas given by the respective references (Atkinson et al., 2004; Sander et al., 2006). Values of $k_{7}$ differed by $24 \%$ (constantly over the temperature and pressure range of our study): from IUPAC (Atkinson et al., 2004) $k_{7,(298 \mathrm{~K})}=9.8 \times 10^{-12} \mathrm{~cm}^{3}$ molecules $^{-1} \mathrm{~s}^{-1}$ and from JPL (Sander et al., 2006) $k_{7,(298 \mathrm{~K})}=7.4 \times$ $10^{-12} \mathrm{~cm}^{3}$ molecules ${ }^{-1} \mathrm{~s}^{-1}$. The calculated JPL value is consistent with the value $\left(k_{7,(\sim 298 \mathrm{~K})}=(7.4 \pm 1.3) \times 10^{-12}\right.$ $\mathrm{cm}^{3}$ molecules $\mathrm{s}^{-1}$ ) measured directly at atmospheric pressure by Bohn and Zetzsch (1997). We therefore prefer 

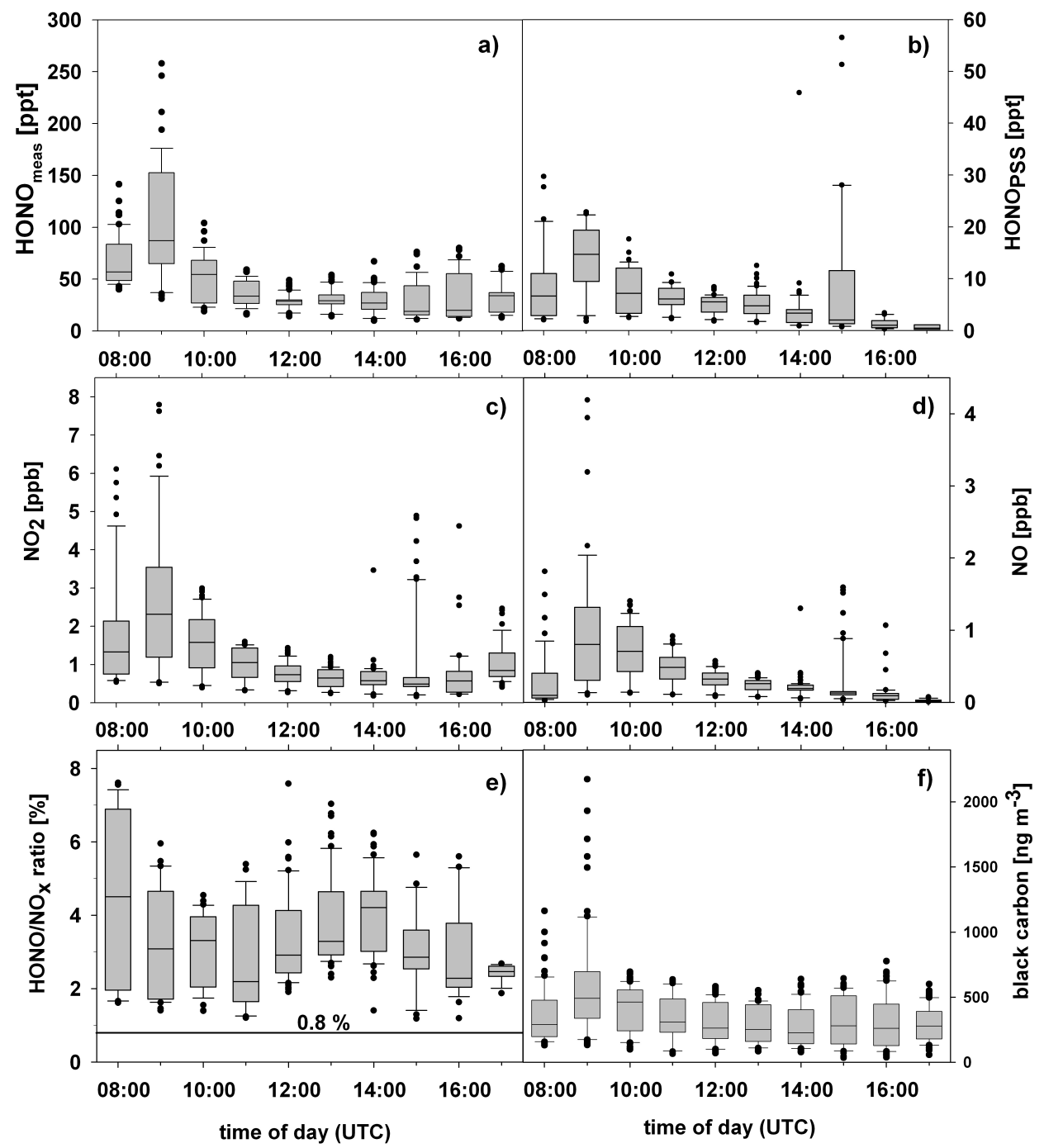

Fig. 2. Daytime cycles of (a) measured HONO mixing ratios, $\mathrm{HONO}_{\text {meas }}$ (b) calculated HONO mixing according to Eq. (1), HONO $\mathrm{PSS}$ (c) $\mathrm{NO}_{2}$ and (d) $\mathrm{NO}$ mixing ratios as well as (e) $\mathrm{HONO} / \mathrm{NO}_{\mathrm{x}}$ ratios with the value of $0.8 \%$ for direct emissions (Kurtenbach et al., 2001) marked as black line and black carbon concentration (f). The boxes and whiskers represent a one hour time interval (centred in the middle) of five minute data (22-72 data points) of 7 cloud free days ( $21,22,23,25,26,27$ November and 2 December). The upper ends of the boxes represent the 75 th percentile, the lower bounds the 25 th percentile and the line within the boxes the median. The upper whisker marks the last point within the 90th percentile and the lower whisker that of the 10th percentile. Data points outside the 10th and 90th percentile are marked individually as dots.

this value and use it for our calculations of the PSS. For the bimolecular reaction of $\mathrm{HONO}$ and $\mathrm{OH}$ (R6), a rate constant of $k_{6298 \mathrm{~K}}=6.0 \times 10^{-12} \mathrm{~cm}^{3}$ molecules ${ }^{-1} \mathrm{~s}^{-1}$ was taken from Atkinson et al. (2004).

Uncertainties in the PSS mainly originate from $\mathrm{OH}$ measurements with an accuracy of $\pm 18 \%$. This has some influence on HONO formation via Reaction (R7) but not much influence on the loss term, since HONO loss via Reaction (R7) was mostly less than $5 \%$ of the total loss (R5 and R6) during the whole campaign. As $\mathrm{OH}$ measurements may possibly suffer from interferences, the $\left[\mathrm{HONO}_{\mathrm{PSS}}\right]$ values are rather an upper limit. As a consequence, the unknown HONO source discussed in Sect. 3.3 is rather a lower limit. There is also some uncertainty in the $j(\mathrm{HONO})$ values since the portions of the upwelling part of the radiation measured at the site were about $0.3-0.5$ of the downwelling (direct + diffuse). These high albedo values were presumably caused by the white container roofs and the aluminium scaffold below the sensor. As the minimum HONO lifetime (inverse photolysis frequency) is about $15 \mathrm{~min}$ around noon, our measurements at the $10 \mathrm{~m}$ scaffold do not reflect the local situation but an integration over a "footprint area" (Schmid, 2002; Vesala et al., 2008). Therefore, we chose an albedo value for UV radiation of the surrounding pine forest of 0.05 (Cancillo et al., 2005) which is more representative. 
Figure 2 summarizes the diurnal courses of HONO and $\mathrm{NO}_{\mathrm{x}}$ for 7 cloud free days. On the 27th around noon, fair weather clouds were passing. These data points were rejected for further analysis to exclude effects from fluctuations in $j(\mathrm{HONO})$. On 2 December, data was taken from a second LOPAP at $1 \mathrm{~m}$ height as there were no data available from the $10 \mathrm{~m}$ instrument. Both instruments have been demonstrated to agree within $12 \%$ under dry field conditions in side-byside measurements (Sörgel et al., 2011). Assuming efficient vertical mixing during the day, HONO mixing ratios at $1 \mathrm{~m}$ and $10 \mathrm{~m}$ height can be expected to be similar (Sörgel et al., 2011).

The portion of HONO formed by known reactions in the gas phase ([HONOPSS $]$, Fig. $2 b)$ is not negligible. The median contribution is $20 \%$ ( 25 percentile is $13 \%$ ) of the measured HONO mixing ratios. On the other hand, the gas phase formation can explain only part of the measured HONO, as $75 \%$ of the [HONOPSS $]$ values contribute less than $30 \%$ to the measured values. $\mathrm{HONO}_{\text {meas }}, \mathrm{HONO}_{\mathrm{PSS}}$, NO and $\mathrm{NO}_{2}$ have a similar diurnal cycle with the most pronounced feature being the maximum values around 09:00 UTC. This could be explained by local emissions which were trapped in the stable boundary layer before the breakup of the inversion in the morning. In the afternoon (15:00-16:00), this peak occurs less pronouncedly in $\mathrm{NO}$ and $\mathrm{NO}_{2}$ but very clearly in the PSS values, as $\mathrm{OH}$ values are about twice $\left(\sim 3 \times 10^{6}\right.$ molecules $\left.\mathrm{cm}^{-3}\right)$ those at 09:00. From Fig. $2 \mathrm{~b}$ and $\mathrm{d}$ one can infer that [HONOPSS] values are correlated to NO mixing ratios $\left(r^{2}=0.78\right)$. Correlations to other input parameters of the PSS are low $\left([\mathrm{OH}] r^{2}=0.006 ; j\right.$ (HONO) $\left.r^{2}=0.01\right)$. Therefore, NO availability seems to be a driving force for HONO gas phase chemistry. Measured HONO mixing ratios (Fig. 2a) have a coefficient of determination $r^{2}=0.49$ with $\left[\mathrm{NO}_{2}\right]$, and $r^{2}=0.36$ with [NO]. The relation of the HONO formation rate (which is more appropriate than HONO mixing ratios) and $\mathrm{NO}_{2}$ is discussed in detail in Sect. 3.3.

$\mathrm{HONO} / \mathrm{NO}_{\mathrm{x}}$ ratios reach their daytime maximum in the early afternoon with median values around $4 \%$ (Fig. 2e), implying efficient $\mathrm{NO}_{\mathrm{x}}$ conversion. On the other hand, the maximum can also be attributed to sources independent from ambient $\mathrm{NO}_{\mathrm{x}}$ values such as soil emissions (Su et al., 2011), and $\mathrm{HNO}_{3}$ photolysis at surfaces (Zhou et al., 2011), which are not affected by the declining $\mathrm{NO}_{\mathrm{x}}$ values in the early afternoon.

\subsubsection{Including the parameterized heterogeneous HONO formation into PSS calculations}

To sum up known HONO formation pathways, the heterogeneous formation $((\mathrm{R} 1) /(\mathrm{R} 2))$ which was measured during nighttime may be included as an additional source in the PSS (e.g. Alicke et al., 2002, 2003) with the assumption that (R1/R2) continue at daytime in the same manner as at night.
This assumption may not be true because even at night HONO formation (release) is not proceeding at the same rate all night. Studies about HONO fluxes (Harrison and Kitto, 1994; Harrison et al., 1996; Stutz et al., 2002, 2004) explained that measured HONO formation is a net process (pseudo steady state) of release and deposition (see also discussion in Vogel et al., 2003). A recent study by Wong et al. (2011) provides detailed information about HONO formation and deposition in the Nocturnal Boundary Layer (NBL) by combining vertical gradient measurements with 1D model calculations. According to their results the ground surface accounts for most $(\sim 70 \%)$ of the HONO formation by $\mathrm{NO}_{2}$ conversion but also for most of the loss $(\sim 70 \%)$. This confirms previous results from ground based field measurements (Harrison and Kitto, 1994; Stutz et al., 2002; Veitel, 2002; Kleffmann et al., 2003; Zhang et al., 2009; Sörgel et al., 2011), aircraft profiles (Zhang et al., 2009) and modelling (Vogel et al., 2003) that the ground surface is a major source of HONO. Hence, turbulent exchange has a significant impact on near surface HONO mixing ratios as already proposed by Febo et al. (1996). These authors found a good correlation of HONO with radon, which is exclusively emitted from the ground. Furthermore, profiles from recent aircraft measurements were closely related to atmospheric stability with higher HONO values close to the ground and steeper gradients during stable conditions (Zhang et al., 2009). Therefore, mixing ratios are also expected to be controlled by the mixed volume which determines the surface to volume ratio $(S / V)$. The conventional way to account for changes in $S / V$ is the scaling of HONO or HONO production $\left(P_{\mathrm{HONO}}\right)$ by $\mathrm{NO}_{2}$ or $\mathrm{NO}_{\mathrm{x}}$ (e.g. Alicke et al., 2002, 2003). It is assumed that $\mathrm{NO}_{\mathrm{x}}$ is also emitted close to the ground, and therefore is also sensitive to $S / V$ and $\mathrm{NO}_{2}$ is the precursor of HONO. As local sources/sinks of the compounds used for scaling (e.g. $\mathrm{NO}_{\mathrm{x}}$ ) may disturb the HONO/NO ratio, Su et al. (2008a) proposed a combined scaling using also black carbon (BC) and carbon monoxide (CO). To our knowledge, only two recent studies (Yu et al., 2009; Sörgel et al., 2011) tried to address $S / V$ (ground and aerosol) directly by using inversion layer heights from SODAR measurements to estimate mixed volumes. However, at night a stable boundary layer is formed where only intermittent turbulence provides some mixing (Stull, 1988). Therefore, a mixed volume cannot easily be defined. Apart from that, $\mathrm{NO}_{2}$ conversion frequencies measured in different environments around the world are all within a quite narrow range from 0.4 to $1.8 \% \mathrm{~h}^{-1}$ as summarized by Su et al. (2008a) and Sörgel et al. (2011). Conversion frequencies ( $\left.F_{\mathrm{HONO}, \text { night }}\right)$ of $0.9-2 \% \mathrm{~h}^{-1}$ for individual nights and a mean value of $1.5 \pm 0.6 \% \mathrm{~h}^{-1}$ were derived in this study using the approach of Alicke et al. (2002).

In our study, nighttime HONO formation occurs presumably by Reactions (R1) and (R2). Formation through Reactions (R3), (R4) and (R7), all involving NO, is not considered to be important since HONO typically increased 
from sunset (17:30 UTC) to midnight, when NO mixing ratios were mostly (93\%) below the detection limit (LOD) of 6 ppt. Only 87 of 1232 five-minute mean values were above the LOD with median mixing ratios of $8 \mathrm{ppt}$, respectively. Therefore, a linear regression of the $\mathrm{HONO} / \mathrm{NO}_{\mathrm{x}}$ ratio and $\mathrm{HONO} / \mathrm{NO}_{2}$ ratio for all night time data yields a slope of 1.0 and an intercept of $0.02 \%\left(r^{2}=0.9986\right)$. Thus, both ratios can be regarded as equivalent during nighttime. There are no clear indications about the contribution of direct emissions. The closest emissions sources were the industrial area of Huelva (shortest distance $\sim 15 \mathrm{~km}$ ) and the city of Huelva (city centre about $20 \mathrm{~km}$ ). Thus, transport times are in the range from one to two hours. Applying a conversion frequency for $\mathrm{NO}_{2}$ to $\mathrm{HONO}$ of about $1 \% \mathrm{~h}^{-1}$, which is within the range of published values (see above), yields a $1-2 \%$ increase in $\mathrm{HONO} / \mathrm{NO}_{\mathrm{x}}$ during the transport. Thus, $\mathrm{HONO}$ mixing ratios reaching the site are already two to threefold those originally emitted $\left(\mathrm{HONO} / \mathrm{NO}_{\mathrm{x}} \sim 0.8 \%\right.$, Kurtenbach et al., 2001). Using the wind sector classification for the DOMINO site of Diesch et al. (2011) we found indeed lower $\mathrm{HONO} / \mathrm{NO}_{\mathrm{x}}$ values at night for air masses passing Huelva than for other air masses from the continent. If this can be attributed to direct emissions is unclear. The transport occurs along the coast and therefore also mixing with HONO depleted marine air can cause lower $\mathrm{HONO} / \mathrm{NO}_{\mathrm{x}} . \mathrm{HONO} / \mathrm{NO}_{\mathrm{x}}$ values for Huelva are indeed within the range of those for the "clean" marine sector. Therefore, we assume that Reactions (R1)/(R2) is the dominant nightime HONO formation pathway at the DOMINO site.

Generally, a stable boundary layer is formed at nighttime in which turbulence is suppressed, whereas during daytime a mixed layer develops which is much more turbulent (e.g. Stull, 1988). This has two opposing effects on Reactions (R1) and (R2) (especially if the ground surface is the dominant source).

1. During daytime turbulence is enhanced which means that $\mathrm{NO}_{2}$ is efficiently transported to the reactive surface.

2. The surface to volume ratio $(S / V)$ is lower during daytime, as the mixed volume increases (mixed layer), thus less reactive surface area per volume is available.

If no deposition or advection occurs, $\mathrm{HONO} / \mathrm{NO}_{\mathrm{x}}$ will rise continuously from sunset to sunrise, as photolysis is absent. We found decreasing $\mathrm{HONO} / \mathrm{NO}_{\mathrm{x}}$ in the late night until sunrise which may point to the dominance of loss processes of HONO, e.g. deposition. Therefore, it is questionable if Reactions (R1) and (R2), i.e. heterogeneous formation, can simply be transferred to daytime conditions. As will be shown in Sect. 3.3 (Figs. 3 and 4), including this dark heterogeneous source as a daytime source in Eq. (3) to calculate the magnitude of the unknown daytime source $P_{\text {unknown }}$ yields mainly negative values in the early morning. This points to a missing sink like deposition (or a smaller source or both). Therefore, we did not consider this heterogeneous source for the PSS calculations.

\subsection{Missing daytime source}

As shown in Sect. 3.2 (Fig. 2) measured HONO values $\left(\mathrm{HONO}_{\text {meas }}\right)$ almost always exceed the $[\mathrm{HONO}]_{\mathrm{PSS}}$ values. Thus, an additional (unknown) HONO daytime source exists. Equation (2), which is similar to that of Su et al. (2008b), sums up the processes influencing HONO mixing ratios.

$$
\begin{aligned}
& \frac{d \mathrm{HONO}}{d t}=\text { sources }- \text { sinks }= \\
& \quad=\left(P_{\mathrm{NO}+\mathrm{OH}}+P_{\mathrm{emis}}+P_{\mathrm{het}}+P_{\text {unknown }}\right) \\
& \quad-\left(L_{\mathrm{phot}}+L_{\mathrm{HONO}+\mathrm{OH}}+L_{\mathrm{dep}}\right)+T_{\mathrm{v}}+T_{\mathrm{h}}
\end{aligned}
$$

The source/production $\left(P_{\mathrm{x}}\right)$ terms consist of the gas phase formation $\left(P_{\mathrm{NO}+\mathrm{OH}}, \mathrm{R} 7\right)$, the dark heterogeneous formation ( $P_{\text {het }}$, via R1/R2) and direct emissions $\left(P_{\text {emis }}\right) . P_{\text {unknown }}$ is the unknown HONO daytime source. The sink/loss processes $\left(L_{\mathrm{y}}\right)$ are photolysis $\left(L_{\text {phot }}, \mathrm{R} 5\right)$, reaction of HONO with $\mathrm{OH}\left(L_{\mathrm{HONO}+\mathrm{OH}}, \mathrm{R} 6\right)$, and dry deposition $\left(L_{\mathrm{dep}}\right)$. Note that the terms for vertical $\left(T_{\mathrm{v}}\right)$ and horizontal advection $\left(T_{\mathrm{h}}\right)$ can mimic source or sink terms depending on the HONO mixing ratios of the advected air relative to that of the measurement site (and height). If HONO has a ground source (or near surface aerosol source), $T_{\mathrm{v}}$ mimics a sink term, as vertical mixing dilutes HONO formed near the ground (see also discussion Sect. 3.2.2). The magnitude of $T_{\mathrm{V}}$ (without the contribution of the rising boundary layer in the morning) can be estimated by using a parameterization for dilution by background air provided by Dillon et al. (2002), i.e. $T_{\mathrm{v}}=k_{\text {(dilution) }}\left([\mathrm{HONO}]-[\mathrm{HONO}]_{\text {background }}\right)$. Assuming a $k_{\text {(dilution) }}$ of $0.23 \mathrm{~h}^{-1}$ (Dillon et al., 2002), a [HONO $]_{\text {background }}$ value of about 10 ppt (Zhang et al., 2009) and taking mean noontime [HONO] values of $35 \mathrm{ppt}$ we can derive that $T_{\mathrm{v}}$ is about $4 \mathrm{ppth}^{-1}$. This value is about the same magnitude as $L_{\text {dep }}$ as already suggested by Su et al. (2008b).

$L_{\text {dep }}$ can be parameterized by multiplying the measured HONO concentration with the dry deposition velocity and then scaling by the mixing height, in order to scale the loss at the ground to its contribution to total HONO loss in the mixed volume. Taking a deposition velocity of $2 \mathrm{~cm} \mathrm{~s}^{-1}$ (Harrison et al., 1996; Su et al., 2008b) and a mixing height of $1000 \mathrm{~m}, L_{\text {dep }}$ is in the order of a few $\mathrm{ppth}^{-1}$ in our study which is indeed small ( $<3 \%$ of $L_{\text {phot }}$ 09:00-15:30 UTC for 7 clear days $N=312$ ) compared to $L_{\text {phot }}$. As is discussed in more detail later, the relative contribution of $L_{\text {dep }}$ might be higher in the morning and evening hours, as $L_{\text {phot }}$ is smaller and a stable boundary layer is formed (mixed height $\ll 1000 \mathrm{~m}$, or stable conditions). Overall, $T_{\mathrm{v}}$ and $L_{\text {dep }}$ are small loss terms (compared to $L_{\text {phot }}$ ). If their contributions are larger than assumed (especially in the morning and evening), $P_{\text {unknown }}$ is underestimated during these periods.

$P_{\text {emis }}$ cannot easily be determined, because its contribution varies with the source strength, the HONO lifetime, the 


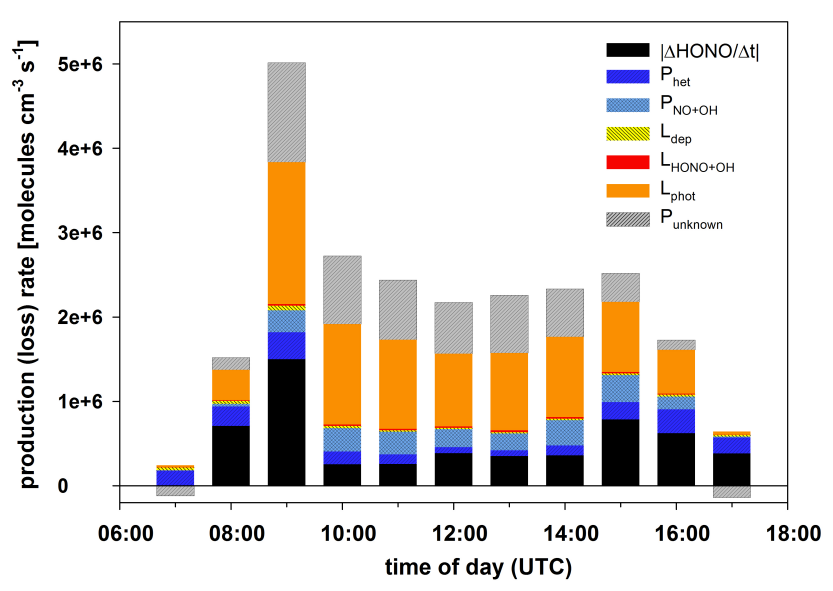

Fig. 3. Contributions of production (bluish colours) and loss terms (hourly means 21 November to 5 December) as well as the unknown daytime HONO source $P_{\text {unknown }}$ from Eq. (3).

horizontal wind speed and wind direction. Again, this contribution is assumed to be highest in the morning and in the evening (longer lifetimes $=$ longer transport range). As there were no collocated emission sources, directly emitted HONO only contributed to the horizontal advection term $\left(T_{\mathrm{h}}\right)$. Measured $\mathrm{HONO} / \mathrm{NO}_{\mathrm{x}}$ ratios were always higher than those reported for direct emissions (max. reported $0.8 \%$ ) (Pitts et al., 1984; Kirchstetter et al., 1996; Kurtenbach et al., 2001; Kleffmann et al., 2003). Thus, no pure direct emissions were measured. Therefore, the contribution of directly emitted HONO to the HONO budget is uncertain, but $P_{\text {emis }}$ can be assumed to be of minor importance around noon, as $\mathrm{NO}_{\mathrm{x}}$ values exhibit a minimum and show low variability. Furthermore, HONO lifetime is only about $15 \mathrm{~min}$, so at typical wind speeds of about $3 \mathrm{~m} \mathrm{~s}^{-1}$, emissions have to occur within $3 \mathrm{~km}$ to reach the site within their lifetime. Additionally, minimum values of $\mathrm{HONO} / \mathrm{NO}_{\mathrm{x}}$, which indicate fresh emissions, are independent of wind direction.

Simplifying Eq. (2), we can derive the unknown HONO daytime source, $P_{\text {unknown }}$, from Eq. (3).

$$
\begin{gathered}
P_{\text {unknown }}=L_{\mathrm{HONO}+\mathrm{OH}}+L_{\mathrm{phot}}+L_{\mathrm{dep}}-P_{\mathrm{NO}+\mathrm{OH}} \\
-P_{\text {het }}+\frac{\Delta \mathrm{HONO}}{\Delta t}
\end{gathered}
$$

$P_{\text {unknow }}$ is not equal to $\mathrm{OH}$ production from $\mathrm{HONO}$ as for net $\mathrm{OH}$ formation a simple balancing of gas phase sources and sinks without further assumptions is applicable $\left(P_{\mathrm{OH}}=\right.$ $\left.L_{\text {phot }}-L_{\mathrm{HONO}+\mathrm{OH}}-P_{\mathrm{NO}+\mathrm{OH}}\right)$. Mean diurnal contributions of the single terms and the values of $P_{\text {unknown }}$ are presented in Fig. 3. $P_{\mathrm{NO}+\mathrm{OH}}, L_{\text {phot }}, L_{\mathrm{HONO}+\mathrm{OH}}$ were calculated from measured values as already described for the PSS (Sect. 3.2.1). $P_{\text {het }}$ was parameterized from the nighttime $\mathrm{NO}_{2}$ conversion by $P_{\text {het }}(t)=\overline{F_{\mathrm{HONO}, \text { night }}}\left[\mathrm{NO}_{2}\right]$ (Alicke et al., 2002) using $F_{\text {HONO, night }}=1.5 \% \mathrm{~h}^{-1}$ (Sect. 3.2.2). The differential $\mathrm{dHONO} / \mathrm{dt}$ was substituted by the difference
$\Delta \mathrm{HONO} / \Delta t$, which is the mixing ratio difference from the centre of the interval $(5 \mathrm{~min})$ to the centre of the next interval (LOPAP has $5 \mathrm{~min}$ time resolution) and accounts for changes in mixing ratio levels. It became obvious that point to point changes in $\mathrm{HONO}(\Delta \mathrm{HONO} / \Delta t)$ were mostly smaller than the relative error of the instrument $( \pm 12 \%)$, and so we could not account for these changes. Values above this threshold were mainly caused by sharp HONO peaks which were accompanied with peaks in NO and BC. These plumes passed the site mainly in the morning hours (see Figs. 2, 3 and 4) with maximum $\mathrm{HONO}$ values comparable to the nighttime maxima (Fig. 1). This indicates that especially in the morning, the advective term $T_{\mathrm{h}}$ does play a role and the arrival of plumes at the site mimics a source term $(\Delta \mathrm{HONO} / \Delta t>$ $0)$, whereas their fading $(\Delta \mathrm{HONO} / \Delta t<0)$ mimics a sink (Figs. 3 and 4). Also, the contribution of $\Delta \mathrm{HONO} / \Delta t$ to the $\mathrm{HONO}$ budget depends on the integration time of the HONO signal. Comparing 5, 15, 30 and $60 \mathrm{~min}$ values, the highest contribution is associated with the 5 min values and the lowest with the $30 \mathrm{~min}$ values $(60 \mathrm{~min}$ values are possibly already influenced by the diurnal cycle). Besides less influence from advection, the lower contribution of $\Delta \mathrm{HONO} / \Delta t$ to the source and sink terms during the PRIDE-PRD-2004 experiment (Su et al., 2008b) compared to our study could at least partly be caused by the lower time resolution for $\mathrm{HONO}$ measurements in that study.

The contributions of the terms of Eq. (3) to the HONO budget (Fig. 3) are as follows. The reaction between HONO and $\mathrm{OH}\left(L_{\mathrm{HONO}+\mathrm{OH}}\right)$ has a very small contribution to $\mathrm{HONO}$ loss (mostly less than $5 \%$ of $\left.L_{\text {phot }}\right)$. Dry deposition $\left(L_{\mathrm{dep}}\right)$ is also very small (mostly less than $3 \%$ of $L_{\text {phot }}$ ). Around noon the main known HONO source is $P_{\mathrm{NO}+\mathrm{OH}}$. Due to low $\mathrm{NO}_{2}$ levels around noon (see Fig. 2) $P_{\text {het }}$ is also very low during that period. The noon period is clearly dominated by loss via $L_{\text {phot }}$ (the overall dominant loss process) and formation by the unknown HONO source $\left(P_{\text {unknown }}\right) . \quad P_{\text {het }}$ is higher in the morning and evening, respectively, provided that the parameterization (Sect. 2.3.2) is valid. $P_{\text {unknown }}$ is negative (Figs. 3 and 4) in the early morning and evening indicating a missing sink, since more HONO is formed by the "known sources" than is destroyed via photolysis. A likely sink is non-negligible deposition of $\mathrm{HONO}$, whose relative contribution might be higher in the morning and evening hours (mixed height $\ll 1000 \mathrm{~m}$ ).

Figure $4 \mathrm{a}$ shows all calculated values of the unknown HONO source $\left(P_{\text {unknown }}\right)$ in $\mathrm{ppth}^{-1}$ $\left(=7.37 \times 10^{3}\right.$ molecules $\mathrm{cm}^{-3} \mathrm{~s}^{-1}$ at $1000 \mathrm{hPa}$ and $\left.273.15 \mathrm{~K}\right)$ versus $j\left(\mathrm{NO}_{2}\right)$, as former studies (e.g. Vogel et al., 2003; Su et al., 2008b) proposed a correlation of this source to $j\left(\mathrm{NO}_{2}\right)$. Values for $P_{\text {unknown }}$ range from about -700 to $1800 \mathrm{ppth}^{-1}$ (at noontime 10:00-14:00 UTC: $105 \pm 39 \mathrm{ppth}^{-1}$ for 7 clear days $N=195$ ) which is within the range of other rural and urban studies (Kleffmann, 2007). The filled red dots in Fig. 4 are points where $\Delta \mathrm{HONO} / \Delta t$ values were larger than the respective relative errors of the HONO measurements, 

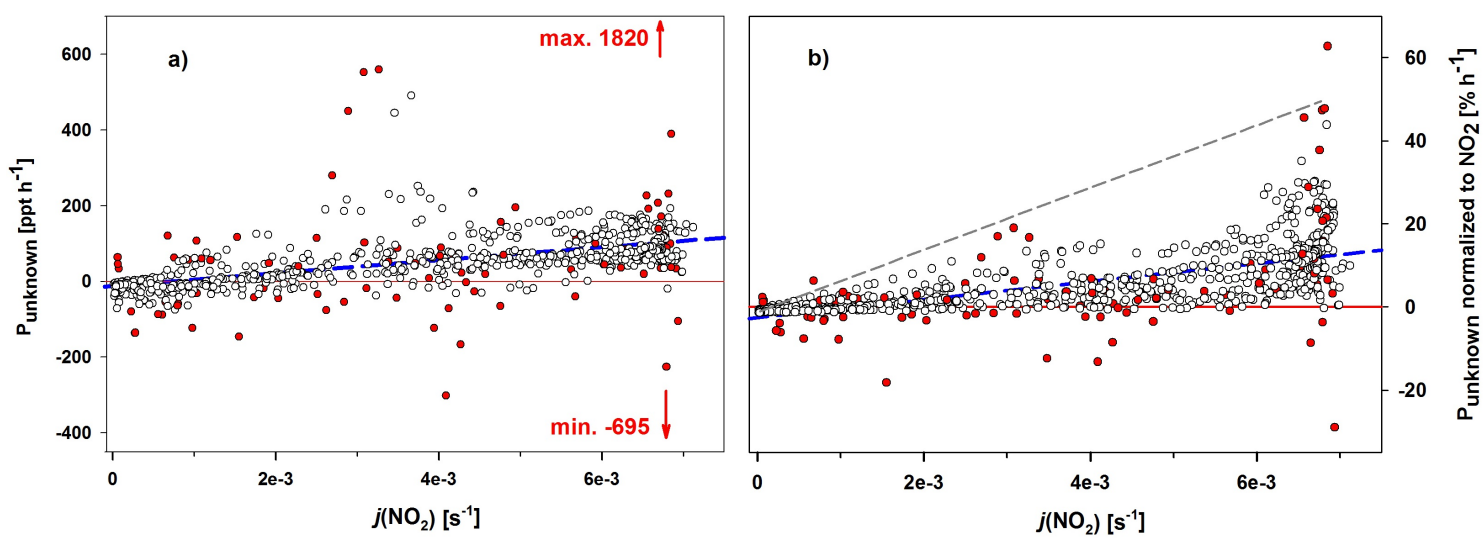

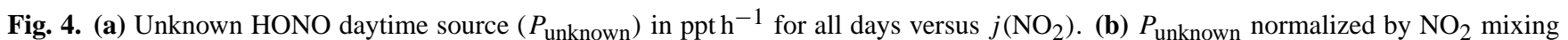
ratios yielding a conversion frequency $\left(\% \mathrm{~h}^{-1}\right)$. Panel (a) contains only data points $(N=753)$ which could be normalized to $\mathrm{NO}_{2}$. Points where $\Delta \mathrm{HONO} / \Delta t$ was larger than the relative error of the LOPAP $( \pm 12 \%)$ are marked as filled red points. Blue dashed lines are linear fits to the data with (a) $r^{2}=0.16$ and (b) $r^{2}=0.38$. The grey dashed line in Fig. 4a presents an upper limit based on the mean of the five lowest points at $\left(j \mathrm{NO}_{2}\right)_{\min }$ and five highest points at $\left(j \mathrm{NO}_{2}\right)_{\max }$.

and thus included in Eq. (3). Applying a linear fit to the data in Fig. 4 a yields a coefficient of determination $\left(r^{2}\right)$ of 0.16 , and thus a rather weak linear correlation of $P_{\text {unknown versus }}$ $j\left(\mathrm{NO}_{2}\right)$.

As light-induced conversion of $\mathrm{NO}_{2}$ is thought to be the most probable source of HONO daytime formation, we normalized the unknown source by the $\mathrm{NO}_{2}$ mixing ratios to improve comparability to other environmental conditions (remote, urban, laboratory). This normalized $P_{\text {unknown }}$ presented in Fig. $4 \mathrm{~b}$ has the same units $\left(\% \mathrm{~h}^{-1}\right)$ as the nightime conversion frequency ( $F_{\mathrm{HONO}}$,night $)$ and can be referred to as a daytime conversion frequency assuming $\mathrm{NO}_{2}$ is the direct precursor as indicated by recent studies of light-induced $\mathrm{NO}_{2}$ conversion (e.g. Stemmler et al., 2006). Figure $4 \mathrm{~b}$ indicates that $\mathrm{NO}_{2}$ levels indeed play an important role, as peak values of the daytime source, when scaled by $\mathrm{NO}_{2}$ mixing ratios, fall below an upper limit of conversion of $P_{\text {unknown,norm, } \max }=\left(7490 \cdot j\left(\mathrm{NO}_{2}\right)-1.2\right) \% \mathrm{~h}^{-1}$. The coefficient of determination of the linear fit to all values (Fig. 4b blue dashed line) increased from 0.16 without to 0.38 with $\mathrm{NO}_{2}$ scaling. The correlation further improved to $r^{2}=0.47$ if only data from clear days were taken and advection events were excluded (Fig. 5 insert). Nevertheless, this means that less than $50 \%$ of the variance is explained by the linear model of the normalized unknown HONO source increasing linearly with $j\left(\mathrm{NO}_{2}\right)$. A possible reason are $\mathrm{HONO}$ sources which are independent of the $\mathrm{NO}_{\mathrm{x}}$ values such as $\mathrm{HNO}_{3}$ photolysis (Zhou et al., 2011) or soil emissions (Su et al., 2011). These sources would cause an overestimation of the conversion frequencies at low ambient $\mathrm{NO}_{\mathrm{x}}$ levels. Nevertheless, normalizing by $\mathrm{NO}_{2}$ values seems to efficiently remove peak values in HONO formation during advection events.

As can be seen from a comparison with the diurnal cycle of the normalized $P_{\text {unknown }}$ in Fig. 5, the contribution of
$P_{\text {het }}$ to daytime HONO is very low during most of the day. While the maximum dark heterogeneous conversion rates are around $2 \% \mathrm{~h}^{-1}$, the normalized unknown source (presumably daytime $\mathrm{NO}_{2}$ conversion frequency) reaches median values of about $14 \% \mathrm{~h}^{-1}$ around noontime, with maximum values up to $43 \% \mathrm{~h}^{-1}$. Around noon $P_{\text {unknown }}$ is thus about 7 to 20 times faster than the parameterized nighttime conversion, which is in agreement with Kleffmann et al. (2003), but a factor of three lower than found by Kleffmann et al. (2005).

\subsection{Potential contributions to the unknown HONO daytime source}

In this section we investigate the contributions of two possible reaction pathways recently investigated in laboratory studies following a light-induced conversion of $\mathrm{NO}_{2}$.

\subsection{1 $\mathrm{NO}_{2}$ conversion on irradiated soot}

We calculated $\mathrm{HONO}$ production rates from the reaction of $\mathrm{NO}_{2}$ on irradiated soot surfaces by extrapolating the reactive uptake coefficients ( $\gamma$-values) derived in a laboratory study (Monge et al., 2010) to conditions we measured in the field. These $\gamma$-values were normalized to the Brunauer-EmmettTeller surface (BET-surface) of the soot samples yielding a mass independent uptake ( $\gamma$-BET). This $\gamma$-BET for $\mathrm{NO}_{2}$ was found to increase with increasing irradiance and with decreasing $\mathrm{NO}_{2}$ mixing ratios (Monge et al. 2010). Therefore, we used an extrapolation to lower $\mathrm{NO}_{2}$ values $(\ll 16 \mathrm{ppb})$ provided by B. D'Anna et al. (personal communication, 2010) leading to higher reactive $\mathrm{NO}_{2}$ uptake in our study (median daytime $\mathrm{NO}_{2}=0.9 \mathrm{ppb}$ ). For simplicity, we took a value of $100 \mathrm{~m}^{2} \mathrm{~g}^{-1}$ as the BET surface for soot, which is between the values (120-140 $\mathrm{m}^{2} \mathrm{~g}^{-1}$ from a propane flame) used by Monge et al. (2010) and a value of $97 \mathrm{~m}^{2} \mathrm{~g}^{-1}$ 


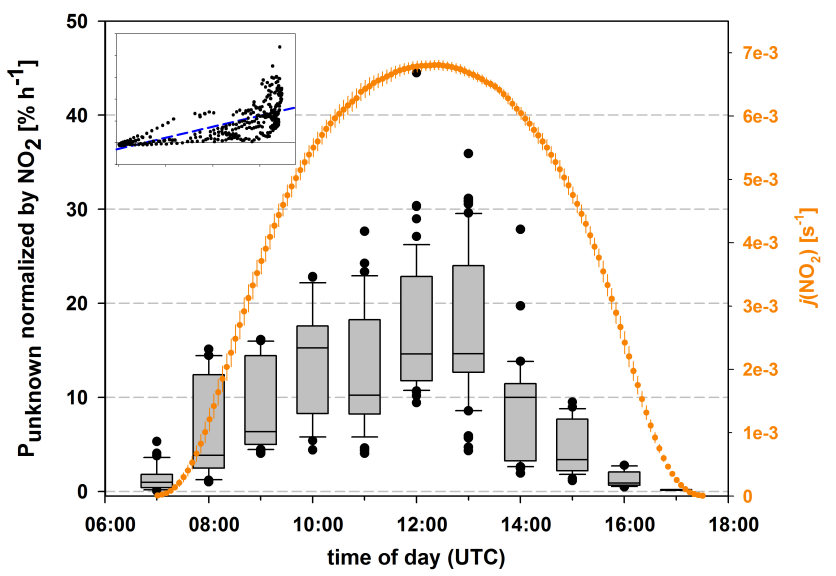

Fig. 5. Diurnal cycle (only daytime) of the unknown HONO source $\left(P_{\text {unknown }}\right)$, normalized by $\mathrm{NO}_{2}$ mixing ratios from 7 cloud-free days (same as Fig. 2). To reflect more stationary conditions, only values where $\Delta \mathrm{HONO} / \Delta t$ was lower than the relative error of the LOPAP were included in this graph. The upper ends of the bars reflect the 75 th percentiles, the lower bounds the 25 th percentiles and the line in between the medians. The upper whiskers represents the 90th percentiles and the lower the 10th percentiles. The minimum number of data points per hour is 17 (07:00), the maximum is 59 (13:00), except for the values close to sunset (17:00) with only 8 data points. Orange dots and bars represent the mean and standard deviation of $j\left(\mathrm{NO}_{2}\right)$ for these days, respectively. The insert shows the same data, but as correlation plot of normalized $P_{\text {unknown }}$ versus $j\left(\mathrm{NO}_{2}\right)$. The $r^{2}$ of the regression line is 0.47 .

published for freshly emitted $\left(81 \mathrm{~m}^{2} \mathrm{~g}^{-1}\right.$ for oxidized) soot (Daly and Horn, 2009). It can be regarded as an upper limit for soot from natural and anthropogenic combustion (Rockne et al., 2000; Fernandes et al., 2003). Black carbon (BC) measurements were taken as proxy soot values. As a further simplification, we used a constant upper limit integrated $(300-420 \mathrm{~nm})$ photon flux of $1.91 \times 10^{16}$ photons $\mathrm{cm}^{-2} \mathrm{~s}^{-1}$ instead of varying it with the solar zenith angle. Therefore, the diurnal variation of the calculated values (Fig. 6) has to be viewed with caution. High values in the morning hours due to $\mathrm{NO}_{2}$ and $\mathrm{BC}$ peaks are actually lower due to lower irradiance values in the morning, and thus lower reactivity. Following Monge et al. (2010), we assumed a HONO production of $60 \%$ of the reactive $\mathrm{NO}_{2}$ uptake. Although we used upper limits for all calculations, the resulting values for the HONO production by this source (Fig. 6) are below $0.6 \%$ of $P_{\text {unknown }}$ in $75 \%$ of all cases $(25$ percentile $=$ $0.2 \%$ and median $=0.3 \%$ ). Thus, for conditions encountered during our campaign (daytime $\mathrm{BC}_{\text {median }} \sim 300 \mathrm{ng} \mathrm{m}^{-3}$ and $\mathrm{NO}_{2 \text {, median }} \sim 0.9 \mathrm{ppb}$ ) this reaction has no noticeable influence on $\mathrm{HONO}$ daytime values.

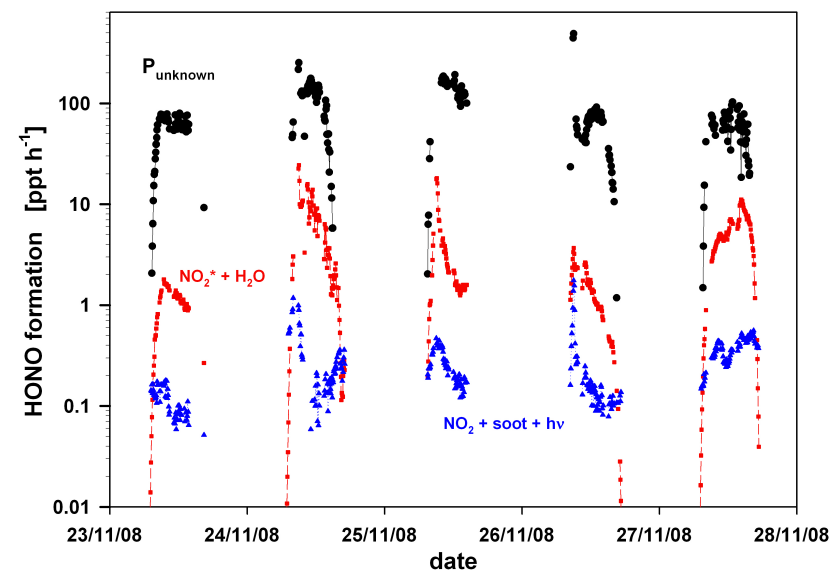

Fig. 6. Comparison of different HONO daytime source strengths (blue: $\mathrm{NO}_{2}+$ soot $+h v$ (Monge et al., 2010); red: $\mathrm{NO}_{2} *+\mathrm{H}_{2} \mathrm{O}, \mathrm{Li}$ et al., 2008) with the unknown HONO daytime source (black).

\subsubsection{Electronically excited $\mathrm{NO}_{2}$ reacting with water vapour}

In order to study the potential contribution of the controversially discussed reaction of electronically excited $\mathrm{NO}_{2}$ with water vapour (R8), we calculated its contribution to $\mathrm{HONO}$ and $\mathrm{OH}$ formation using the expression for $\mathrm{OH}$ production (= HONO production) from Crowley and Carl (1997).

$R_{\mathrm{OH}}=j_{\mathrm{ex}}\left(\mathrm{NO}_{2}\right)\left[\mathrm{NO}_{2}\right] /\left(1+k_{\mathrm{air}}[\mathrm{M}] / k_{8}\left[\mathrm{H}_{2} \mathrm{O}\right]\right)$

$j_{\text {ex }}\left(\mathrm{NO}_{2}\right)$ is the frequency of electronic excitation of $\mathrm{NO}_{2}$ beyond the dissociation threshold $(>420 \mathrm{~nm})$, and $k_{\text {air }}$ $\left(\sim 3 \times 10^{-11}\right.$, Crowley and Carl, 1997) the rate constant for non-reactive quenching with air. $k_{8}$ is the rate constant for the reactive quenching with $\mathrm{H}_{2} \mathrm{O}, k_{8}$, Crowley $=$ $1.2 \times 10^{-14} \mathrm{~cm}^{3}$ molecules ${ }^{-1} \mathrm{~s}^{-1}$ according to Crowley and Carl (1997) and $k_{8, \mathrm{Li}}=1.7 \times 10^{-13} \mathrm{~cm}^{3}$ molecules $^{-1} \mathrm{~s}^{-1} \mathrm{ac}-$ cording to Li et al. (2008). We estimated $j_{\mathrm{ex}}\left(\mathrm{NO}_{2}\right)$ from measured $j\left(\mathrm{NO}_{2}\right)$ by multiplying with a factor of 3.5 (Crowley and Carl, 1997) which is consistent with solar zenith angles $<70^{\circ}\left(\sim 60^{\circ}\right.$ around noontime).

Referring to $k_{8, \mathrm{Li}}$ as an upper limit, $\mathrm{HONO}$ and $\mathrm{OH}$ production rates calculated via Eq. (4) are in the order of a few $\mathrm{ppth}^{-1}$. This contribution to $P_{\text {unknown }}$ is less than $8 \%$ for $75 \%$ of our data, with a median contribution of $4 \%$. Us-

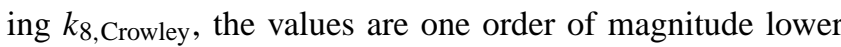
and thus negligible. These findings are in line with calculations from Crowley and Carl (1997) and with recent modelling studies (Wennberg and Dabdub, 2008; Sarwar et al., 2009; Ensberg et al., 2010) where this reaction was found to have a noticeable impact only at very high pollution levels, when using $k_{8, \mathrm{Li}}$. As we do not expect the value for $k_{8}$ to be higher than reported by Li et al. (2008), we do not follow the approach of Wentzell et al. (2010) to explain the unknown HONO source by Reaction (R8) with varying $k_{8}$ alone. A 
very recent paper by Amedro et al. (2011) confirms that the reaction of $\mathrm{Li}$ et al. (2008) followed a multi photon absorption process, and provides an upper limit for reactive quenching which is even lower than that of Crowley and Carl (1997).

\subsubsection{Important ground sources}

The proposed formation of nitrous acid on the ground follows two major pathways. The light induced $\mathrm{NO}_{2}$ conversion via organic photosensitizers (George et al., 2005; Stemmler et al., 2006) and the microbiological formation of nitrite in the soil and the volatilization to the atmosphere as HONO (Kubota and Asami, 1985; Su et al., 2011). As recent measurements of the photolysis of adsorbed $\mathrm{HNO}_{3}$ (Zhu et al., 2010) found $\mathrm{NO}_{2} *$ as the main photolysis product, Zhou et al. (2011) assume that $\mathrm{HONO}$ formation by $\mathrm{HNO}_{3}$ photolysis also follows the mechanism of $\mathrm{NO}_{2}$ conversion provided by George et al. (2005) and Stemmler et al. (2006). Adsorbed $\mathrm{HNO}_{3}$ therefore acts as a reservoir or a source of $\mathrm{NO}_{\mathrm{x}}$ in rural environments (Zhou et al., 2002b, 2003, 2011). One might speculate if the reaction of $\mathrm{NO}_{2} *$ formed by $\mathrm{HNO}_{3}$ photolysis at the surface with adsorbed water is also enhanced with regard to the gas phase Reaction (R8), and thus can act as source of $\mathrm{HONO}$ from $\mathrm{HNO}_{3}$ photolysis. The relative contribution of $\mathrm{HNO}_{3}$ photolysis to direct $\mathrm{NO}_{2}$ conversion increases with surface nitrate loading and decreasing $\mathrm{NO}_{\mathrm{x}}$ values. This might be reflected in our measurements as some of the highest conversion frequencies (Fig. 4b) were measured on a "clean day" $\left(\mathrm{NO}_{\mathrm{x}}<0.5 \mathrm{ppb}\right)$. For a rough estimate of the contribution of direct $\mathrm{NO}_{2}$ conversion (on aerosol and ground surfaces) we took the estimates of Stemmler et al. (2007) which are about $1 \mathrm{ppth}^{-1}$ for humic acid aerosol and about $700 \mathrm{ppth}^{-1}$ for conversion at the soil surface in a $100 \mathrm{~m}$ mixed height at $20 \mathrm{ppb} \mathrm{NO}_{2}$. We scaled these values to $1 \mathrm{ppb} \mathrm{NO}$ (observed $\mathrm{NO}_{2}$ values). As already concluded by Stemmler et al. (2007) the contribution of the aerosol is negligible $\left(\sim 0.05 \mathrm{ppth}^{-1}\right)$. The ground source would contribute about $35 \mathrm{ppth}^{-1}$, i.e. one third of the missing source, applying a linear scaling with $\mathrm{NO}_{2}$.

Regarding the soil emissions, there are no soil acidity and nitrate loading data available for the DOMINO campaign. Therefore, it is at best speculative to derive a HONO source based on the numbers given by Su et al. (2011) as the resulting HONO fluxes vary by orders of magnitude. But as HONO soil flux values in the lowest range (low nitrogen loading and rather high $\mathrm{pH}$ ) can already produce source strength in the right order of magnitude for $P_{\text {unknown }}$, this HONO source might be a substantial contribution during DOMINO.

All calculations about source strength at the ground are very sensitive to vertical mixing. Thus, as already addressed by Zhou et al. (2011), vertical transport determines the discrepancy between the effective source strength relative to that calculated at the measurement height. We conclude that only modelling which takes vertical transport into account can

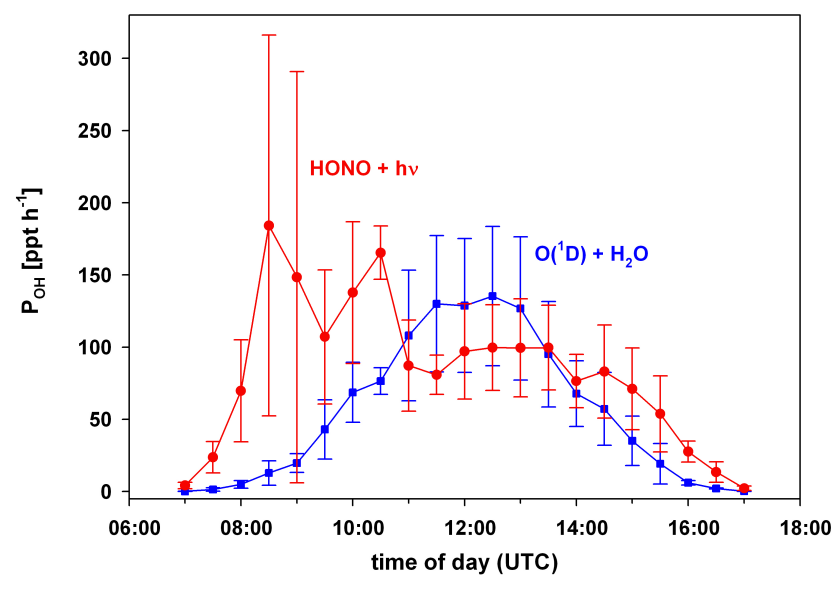

Fig. 7. Comparison for the seven clear days of the campaign of calculated primary $\mathrm{OH}$ production by $\mathrm{HONO}$ and ozone photolysis (means and standard deviations).

yield reliable estimates of the ground source contribution to the missing HONO source.

\subsection{Comparison of $\mathrm{OH}$ radical production from ozone and HONO photolysis}

$\mathrm{OH}$ production rates from ozone photolysis were calculated from ozone, $\mathrm{H}_{2} \mathrm{O}$ measurements and modelled $j \mathrm{O}\left({ }^{1} \mathrm{D}\right)$ values which were scaled by the ratio of measured and modelled $j\left(\mathrm{NO}_{2}\right)$. OH production from $\mathrm{O}\left({ }^{1} \mathrm{D}\right)$ was calculated according to Crowley and Carl (1997) using the rate constants for $\mathrm{O}\left({ }^{1} \mathrm{D}\right)$ quenching by $\mathrm{O}_{2}, \mathrm{~N}_{2}$ and $\mathrm{O}_{3}$ and the reaction with $\mathrm{H}_{2} \mathrm{O}$ taken from the IUPAC recommendations (Atkinson et al., 2004 and updated values from the IUPAC homepage, http://www.iupac-kinetic.ch.cam.ac.uk/). These values are in good agreement ( $\sim 3 \%$ higher) with the same calculations using the recommendations from Sander et al. (2006). The net $\mathrm{OH}$ production by $\mathrm{HONO}$ was calculated by balancing source and sink terms of $\mathrm{OH}$ by $\mathrm{HONO}$ in the gas phase (for $k$ values see Sect. 3.2):

$$
P_{\mathrm{OH}}=j(\mathrm{HONO})[\mathrm{HONO}]-k_{7}[\mathrm{NO}][\mathrm{OH}]-k_{6}[\mathrm{HONO}][\mathrm{OH}]
$$

Although HONO mixing ratios (mean: $30 \mathrm{ppt}$ ) are three orders of magnitude lower than $\mathrm{O}_{3}$ mixing ratios (mean: $35 \mathrm{ppb})$ around noon and $\mathrm{OH}$ production rates by $\mathrm{O}\left({ }^{1} \mathrm{D}\right)$ exceed those of HONO photolysis by about $50 \%$ around noon (11:00-13:00), the integrated daily $\mathrm{OH}$ production is about $20 \%$ lower than that of HONO. Figure 7 shows the higher contribution of $\mathrm{HONO}$ photolysis to the $\mathrm{OH}$ formation in the morning and evening hours due to longer wavelengths (up to $\sim 400 \mathrm{~nm}$ ) associated with HONO photolysis. A special feature of our measurement site are the very high HONO values between 08:00 and 11:00, which can be attributed to advection (see Sects. 3.2 and 3.3). This leads to high $P_{\mathrm{OH}}$ values from HONO photolysis during that period. 


\section{Conclusions}

The unknown HONO daytime source derived from our measurements was normalized by $\mathrm{NO}_{2}$ mixing ratios to improve comparability of HONO source strengths in different environmental and laboratory conditions. For the nighttime formation of HONO, we can exclude that NO plays an important role as $\mathrm{NO}$ was mostly below the detection limit of about $6 \mathrm{ppt}$. Inclusion of the parameterized nighttime HONO formation from $\mathrm{NO}_{2}\left(1.5 \% \mathrm{~h}^{-1}\right.$ in this study) as an additional source into the calculations of the unknown HONO daytime source $\left(P_{\text {unknown }}\right)$ yields mainly negative values in the early morning. This indicates the relevance of loss terms not taken into account (e.g. deposition) or overestimation of the dark heterogeneous formation in the morning and evening. Restricting the analysis only to cloud free days and the time around noon, when faster HONO photolysis leads to lifetimes around $15 \mathrm{~min}$ and other loss processes for $\mathrm{HONO}$ are small compared to loss by photolysis, establishment of a PSS can be assumed. The mean source strength of $P_{\text {unknown }}$ under these conditions was about $100 \mathrm{ppth}^{-1}$ and thus in the lower range of values reported in the literature. Nevertheless $P_{\text {unknown }}$ was the dominant HONO source during day. The normalized unknown $\mathrm{HONO}$ source (or $\mathrm{NO}_{2}$ conversion frequency, if we assume that $\mathrm{NO}_{2}$ is the precursor) varied from slightly negative values in the morning and evening to an upper limit correlated with $j\left(\mathrm{NO}_{2}\right)$. High median daytime $\mathrm{NO}_{2}$ conversion frequencies of $\sim 14 \% \mathrm{~h}^{-1}$ were found around noon, in addition to the $1.5 \% \mathrm{~h}^{-1} \mathrm{HONO}$ formation rate observed during night.

Our results indicate light-induced HONO formation, possibly via conversion of $\mathrm{NO}_{2}$ as indicated by lab experiments. This source is about an order of magnitude stronger than HONO formation during nighttime. We compared the $\mathrm{HONO}$ net source to values calculated for light-induced $\mathrm{NO}_{2}$ uptake on soot (Monge et al., 2010) and the reaction of electronically excited $\mathrm{NO}_{2}^{*}$ with water vapour. The contribution of these reactions to HONO daytime values was mostly less than $10 \%$ and cannot explain the HONO source strength derived in our study. Other processes like light-induced conversion of $\mathrm{NO}_{2}$ on irradiated organic materials like humic acids (Stemmler et al., 2006), or soil emissions (Su et al., 2011) might be more important. Additional measurements including detailed speciation of organic aerosols and determination of humic acids on ground and canopy surfaces are needed to quantify their contribution. Furthermore, a detailed assessment of the contribution of the ground sources requires profound knowledge of boundary layer processes. The unknown HONO daytime source is essential contribution to primary $\mathrm{OH}$ production, as photolysis of $\mathrm{HONO}$ exceeded the $\mathrm{OH}$ formation by ozone photolysis by $20 \%$.
Acknowledgements. The authors gratefully acknowledge financial support by the German Science foundation (DFG projects ZE 792/4-1 and HE5214/4-1) and by the Max Planck Society. We are grateful to Ralph Dlugi and Thomas Foken for intensive and fruitful discussions. We thank Ivonne Trebs and Franz-Xaver Meixner from the Max Planck Institute for Chemistry for providing instruments and equipment, and the Spanish National Institute of Aerospace Technology (INTA) for hosting the campaign

Edited by: T. Karl

\section{References}

Acker, K., Möller, D., Wieprecht, W., Meixner, F. X., Bohn, B., Gilge, S., Plass-Dülmer, C., and Berresheim, H.: Strong daytime production of $\mathrm{OH}$ from $\mathrm{HNO}_{2}$ at a rural mountain site, Geophys. Res. Lett., 33, L02809, doi:10.1029/2005GL024643, 2006.

Alicke, B., Platt, U., and Stutz, J.: Impact of nitrous acid photolysis on the total hydroxyl radical budget during the Limitation of Oxidant Production Pianura/Padana Produzione di Ozono study in Milan, J. Geophys. Res., 107, 8196, doi:10.1029/2000JD000075, 2002.

Alicke, B., Geyer, A., Hofzumahaus, A., Holland, F., Konrad, S., Pätz, H. W., Schäfer, J., Stutz, J., Volz-Thomas, A., and Platt, U.: $\mathrm{OH}$ formation by HONO photolysis during the BERLIOZ experiment, J. Geophys. Res., 108, 8247, doi:10.1029/2001JD000579, 2003.

Amedro, D., Parker, A. E., Schoemaecker, C., and Fittschen, C.: Direct observation of $\mathrm{OH}$ radicals after $565 \mathrm{~nm}$ multi-photon excitation of $\mathrm{NO}_{2}$ in the presence of $\mathrm{H}_{2} \mathrm{O}$, Chem. Phys. Lett., 513, 12-16, 2011

Ammann, M., Rössler, E., Strekowski, R., and George, C.: Nitrogen dioxide multiphase chemistry: Uptake kinetics on aqueous solutions containing phenolic compounds, Phys. Chem. Chem. Phys., 7, 2513-2518, 2005.

Andres-Hernandez, M. D., Notholt, J., Hjorth, J., and Schrems, O.: A DOAS study on the origin of nitrous acid at urban and nonurban sites, Atmos. Environ., 30, 175-180, 1996.

Arens, F., Gutzwiller, L., Baltensperger, U., Gäggler, H. W., and Ammann, M.: Heterogeneous reaction of $\mathrm{NO}_{2}$ on diesel soot particles, Environ. Sci. Technol., 35, 2191-2199, 2001.

Atkinson, R., Baulch, D. L., Cox, R. A., Crowley, J. N., Hampson, R. F., Hynes, R. G., Jenkin, M. E., Rossi, M. J., and Troe, J.: Evaluated kinetic and photochemical data for atmospheric chemistry: Volume $\mathrm{I}$ - gas phase reactions of $\mathrm{O}_{\mathrm{x}}, \mathrm{HO}_{\mathrm{x}}, \mathrm{NO}_{\mathrm{x}}$ and $\mathrm{SO}_{\mathrm{x}}$ species, Atmos. Chem. Phys., 4, 1461-1738, doi:10.5194/acp-41461-2004, 2004.

Aubin, D. G. and Abbatt, J. P. D.: Interaction of $\mathrm{NO}_{2}$ with hydrocarbon soot: focus on HONO yield, surface modification, and mechanism, J. Phys. Chem. A, 111, 6263-6273, 2007.

Bejan, I., Abd el Aal, Y., Barnes, I., Benter, T., Bohn, B., Wiesen, P., and Kleffmann, J.: The photolysis of ortho-nitrophenols: a new gas phase source of HONO, Phys. Chem. Chem. Phys., 8, 2028-2035, doi:10.1039/b516590c, 2006.

Blitz, M. A.: Comment on "The conical intersection dominates the generation of tropospheric hydroxyl radicals from $\mathrm{NO}_{2}$ and $\mathrm{H}_{2} \mathrm{O}$ ', J. Phys. Chem. A, 114, 8016, 2010.

Bohn, B. and Zetzsch, C.: Rate constants of $\mathrm{HO}_{2}+\mathrm{NO}$ covering atmospheric conditions. 1 . $\mathrm{HO}_{2}$ formed by $\mathrm{OH}+\mathrm{H}_{2} \mathrm{O}_{2}$, J. Phys. 
Chem. A, 101, 1488-1493, 1997.

Calvert, J. G., Yarwood, G., and Dunker, A. M.: An evaluation of the mechanism of nitrous acid formation in the urban atmosphere, Res. Chem. Intermediat., 20, 463-502, 1994.

Cancillo, M. L., Serrano, A., Antón, M., García, J. A., Vilaplana, J. M., and de la Morena, B.: An improved outdoor calibration procedure for broadband ultraviolet radiometers, Photochem. Photobiol., 81, 860-865, 2005.

Carr, S., Heard, D. E., and Blitz, M. A.: Comment on "Atmospheric Hydroxyl Radical Production from Electronically Excited $\mathrm{NO}_{2}$ and $\mathrm{H}_{2} \mathrm{O}$ ", Science, 324, p. 336b, doi:10.1126/science.1166669, 2009.

Cox, R. A.: The photolysis of nitrous acid in the presence of carbon monoxide and sulphur dioxide, J. Photochem., 3, 291-304, 1974.

Crowley, J. N. and Carl, S. A.: OH formation in the photoexcitation of $\mathrm{NO}_{2}$ beyond the dissociation threshold in the presence of water vapor, J. Phys. Chem. A, 101, 4178-4184, 1997.

Daly, H. M. and Horn, A. B.: Heterogeneous chemistry of toluene, kerosene and diesel soots, Phys. Chem. Chem. Phys., 11, 10691076, 2009.

Diesch, J.-M., Drewnick, F., Zorn, S. R., von der WeidenReinmüller, S.-L., Martinez, M., and Borrmann, S.: Variability of aerosol, gaseous pollutants and meteorological characteristics associated with continental, urban and marine air masses at the SW Atlantic coast of Iberia, in preparation, 2011.

Dillon, M. B., Lamanna, M. S., Schade, G. W., Goldstein, A., and Cohen, R. C.: Chemical evolution of the Sacramento urban plume: Transport and oxidation, J. Geophys. Res., 107, 4045, doi:10.1029/2001JD000969, 2002.

Ensberg, J. J., Carreras-Sospedra, M., and Dabdub, D.: Impacts of electronically photo-excited $\mathrm{NO}_{2}$ on air pollution in the South Coast Air Basin of California, Atmos. Chem. Phys., 10, 11711181, doi:10.5194/acp-10-1171-2010, 2010.

Fang, Q., Han, J., Jiang, J., Chen, X., and Fang, W.: The conical intersection dominates the generation of tropospheric hydroxyl radicals from $\mathrm{NO}_{2}$ and $\mathrm{H}_{2} \mathrm{O}$, J. Phys. Chem. A, 114, 4601-4608, 2010.

Febo, A., Perrino, C., and Allegrini, I.: Measurement of nitrous acid in Milan, Italy, by DOAS and diffusion denuders, Atmos. Environ., 30 3599-3609, 1996.

Fernandes, M. B., Skjemstad, J. O., Johnson, B. B., Wells, J. D., and Brooks, P.: Characterization of carbonaceous combustion residues. I. Morphological, elemental and spectroscopic features, Chemosphere, 51, 785-795, 2003.

Finlayson-Pitts, B. J.: Reactions at surfaces in the atmosphere: integration of experiments and theory as necessary (but not necessarily sufficient) for predicting the physical chemistry of aerosols, Phys. Chem. Chem. Phys., 11, 7760-7779, 2009.

Finlayson-Pitts, B. J., Wingen, L. M., Sumner, A. L., Syomin, D., and Ramazan, K. A.: The heterogeneous hydrolysis of $\mathrm{NO}_{2}$ in laboratory systems and in outdoor and indoor atmospheres: An integrated mechanism, Phys. Chem. Chem. Phys., 5, 223-242, 2003.

George, C., Strekowski, R. S., Kleffmann, J., Stemmler, K., and Ammann, M.: Photoenhanced uptake of gaseous $\mathrm{NO}_{2}$ on solid organic compounds: a photochemical source of HONO?, Faraday Discuss., 130, 195-210, 2005.

Gonçalves, M., Dabdub, D., Chang, W. L., Saiz, F., Jorba, O., and Baldasano, J. M.: The impact of different nitrous acid sources in the air quality levels of the Iberian Peninsula, Atmos. Chem. Phys. Discuss., 10, 28183-28230, doi:10.5194/acpd-10-281832010, 2010.

Gustafsson, R. J., Orlov, A., Griffiths, P. T., Cox, R. A., and Lambert, R. M.: Reduction of $\mathrm{NO}_{2}$ to nitrous acid on illuminated titanium dioxide aerosol surfaces: implications for photocatalysis and atmospheric chemistry, Chem. Commun., 37, 3936-3938, 2006.

Gustafsson, R. J., Kyriakou, G., and Lambert, R. M.: The molecular mechanism of tropospheric nitrous acid production on mineral dust surfaces, Chem. Phys. Chem., 9, 1390-1393, 2008.

Gutzwiller, L., Arens, F., Baltensberger, U., Gäggler, H. W., and Ammann, M.: Significance of semivolatile diesel exhaust organics for secondary HONO formation, Environ. Sci. Technol., 36, 677-682, 2002a.

Gutzwiller, L., George, C., Rössler, E., and Ammann, M.: Reaction kinetics of $\mathrm{NO}_{2}$ with resorcinol and 2,7-naphthalenediol in the aqueous phase at different pH, J. Phys. Chem. A, 106, 1204512050, 2002b.

Hanst, P. L., Spence, J. W., and Miller, M.: Atmospheric chemistry of n-nitroso dimethylamine, Environ. Sci. Technol., 11, 403-405, 1977.

Harrison, R. M. and Kitto, A.-M. N.: Evidence for a surface source of atmospheric nitrous acid, Atmos. Environ., 28, 1089-1094, 1994.

Harrison, R. M., Peak, J. D., and Collin, G. M.: Tropospheric cycle of nitrous acid, J. Geophys. Res., 101, 14429-14439, 1996.

Heland, J., Kleffmann, J., Kurtenbach, R., and Wiesen, P.: A new instrument to measure gaseous nitrous acid (HONO) in the atmosphere, Environ. Sci. Technol., 35, 3207-3212, 2001.

Hosaynali Beygi, Z., Fischer, H., Harder, H. D., Martinez, M., Sander, R., Williams, J., Brookes, D. M., Monks, P. S., and Lelieveld, J.: Oxidation photochemistry in the Southern Atlantic boundary layer: unexpected deviations of photochemical steady state, Atmos. Chem. Phys., 11, 8497-8513, doi:10.5194/acp-118497-2011, 2011.

IUPAC Subcommittee on Gas Kinetic Data Evaluation: http://www. iupac-kinetic.ch.cam.ac.uk/, access 10 January 2011.

Jenkin, M. E., Cox, R. A., and Williams, D. J.: Laboratory studies of the kinetics of formation of nitrous acid from the thermal reaction of nitrogen dioxide and water vapour, Atmos. Environ., 22 487498, 1988.

Killus, J. P. and Whitten, G. Z.: Background reactivity in smog chambers, Int. J. Chem. Kinet., 22, 547-575, 1990.

Kinugawa, T., Enami, S., Yabushita, A., Kawasaki, M., Hoffmann, M. R., and Colussi, A. J.: Conversion of gaseous nitrogen dioxide to nitrate and nitrite on aqueous surfactants, Phys. Chem Chem. Phys., 13, 5144-5149, doi:10.1039/C0CP01497D, 2011.

Kirchstetter, T. W., Harley, R. A., and Littlejohn, D.: Measurement of nitrous acid in motor vehicle exhaust, Environ. Sci. Technol., 30, 2843-2849, 1996.

Kleffmann, J.: Daytime sources of nitrous acid (HONO) in the atmospheric boundary layer, Chem. Phys. Chem., 8, 1137-1144, 2007.

Kleffmann, J., Becker, K. H., and Wiesen, P.: Heterogeneous $\mathrm{NO}_{2}$ conversion processes on acid surfaces: possible atmospheric implications, Atmos. Environ., 32, 2721-2729, 1998.

Kleffmann, J., Becker, K. H., Lackhoff, M., and Wiesen, P.: Heterogeneous conversion of $\mathrm{NO}_{2}$ on carbonaceous surfaces, Phys. 
Chem. Chem. Phys., 1, 5443-5450, 1999.

Kleffmann, J., Heland, J., Kurtenbach, R., Lörzer, J., and Wiesen, P.: A new instrument (LOPAP) for the detection of nitrous acid (HONO), Environ. Sci. Pollut. R., 4, 48-54, 2002.

Kleffmann, J., Kurtenbach, R., Lörzer, J., Wiesen, P., Kalthoff, N., Vogel, B., and Vogel, H.: Measured and simulated vertical profiles of nitrous acid - Part I: Field measurements, Atmos. Environ., 37, 2949-2955, 2003.

Kleffmann, J., Benter, T., and Wiesen, P.: Heterogeneous reaction of nitric acid with nitric oxide on glass surfaces under simulated atmospheric conditions, J. Phys. Chem. A, 108, 5793-5799, 2004.

Kleffmann, J., Gavriloaiei, T., Hofzumahaus, A., Holland, F., Koppmann, R., Rupp, L., Schlosser, E., Siese, M., and Wahner, A.: Daytime formation of nitrous acid: A major source of $\mathrm{OH}$ radicals in a forest, Geophys. Res. Lett., 32, L05818, doi:10.1029/2005GL022524, 2005.

Kraus, A. and Hofzumahaus, A.: Field measurements of atmospheric photolysis frequencies for $\mathrm{O}_{3}, \mathrm{NO}_{2}, \mathrm{HCHO}, \mathrm{CH}_{3} \mathrm{CHO}$, $\mathrm{H}_{2} \mathrm{O}_{2}$, and $\mathrm{HONO}$ by UV spectroradiometry, J. Atmos. Chem., 31, 161-180, 1998.

Kubota, M. and Asami, T.: Source of nitrous acid volatilized from upland soils, Soil Sci. Plant Nutr., 31, 35-42, 1985.

Kurtenbach, R., Becker, K. H., Gomes, J. A. G., Kleffmann, J., Lörzer, J. C., Spittler, M., Wiesen, P., Ackermann, R., Geyer, A., and Platt, U.: Investigations of emissions and heterogeneous formation of $\mathrm{HONO}$ in a road traffic tunnel, Atmos. Environ., 35, 3385-3394, 2001.

Lammel, G. and Cape, J. N.: Nitrous acid and nitrite in the atmosphere, Chem. Soc. Rev., 25, 361-369, 1996.

Li, S., Matthews, J., and Sinha, A.: Atmospheric hydroxyl radical production from electronically excited $\mathrm{NO}_{2}$ and $\mathrm{H}_{2} \mathrm{O}$, Science, 319, 1657-1660, doi:10.1126/science.1151443, 2008.

Li, S., Matthews, J., and Sinha, A.: Response to comment on "Atmospheric hydroxyl radical production from electronically excited $\mathrm{NO}_{2}$ and $\mathrm{H}_{2} \mathrm{O}$ ", Science, 324, p. 336c, 2009.

Madronich, S. and Flocke, S., The role of solar radiation in atmospheric chemistry, in: The Handbook of Environmental Chemistry/Reactions and Processes/Environmental Photochemistry Part I: BD 2/Part L, edited by: Boule, P., Springer-Verlag, Heidelberg, 373 (pp. 1-26), 1998.

Martinez, M., Harder, H., Kubistin, D., Rudolf, M., Bozem, H., Eerdekens, G., Fischer, H., Klüpfel, T., Gurk, C., Königstedt, R., Parchatka, U., Schiller, C. L., Stickler, A., Williams, J., and Lelieveld, J.: Hydroxyl radicals in the tropical troposphere over the Suriname rainforest: airborne measurements, Atmos. Chem. Phys., 10, 3759-3773, doi:10.5194/acp-10-3759-2010, 2010.

Monge, M. E., D’Anna, B., Mazri, L., Giroir-Fendler, A., Ammann, M., Donaldson, D. J., and George, C.: Light changes the atmospheric reactivity of soot, P. Natl. Acad. Sci. USA, 107, 66056609, 2010.

NASA.:Ozone over your house, http://jwocky.gsfc.nasa.gov/ teacher/ozone_overhead.html, last access: January 2011.

Ndour, M., D’Anna, B., George, C., Ka, O., Balkanski, Y., Kleffmann, J., Stemmler, K., and Ammann, M.: Photoenhanced uptake of $\mathrm{NO}_{2}$ on mineral dust: Laboratory experiments and model simulations, Geophys. Res. Lett., 35, L05812, doi:10.1029/2007GL032006, 2008.

Perner, D. and Platt, U.: Detection of nitrous acid in the atmosphere by differential optical absorption, Geophys. Res. Lett., 6, 917920, 1979.

Pitts Jr., J. N., Grosjean, D., Cauwenberghe, K. V., Schmid, J. P., and Fitz, D. R.: Photooxidation of aliphatic amines under simulated atmospheric conditions: formation of nitrosamines, nitramines, amides, and photochemical oxidant, Environ. Sci. Technol., 12 946-953, 1978.

Pitts Jr., J. N., Biermann, H. W., Winer, A. M., and Tuazon, E. C.: Spectroscopic identification and measurement of gaseous nitrous acid in dilute auto exhaust, Atmos. Environ., 18, 847-854, 1984.

Raivonen, M., Bonn, B., Sanz, M. J., Vesala, T., Kulmala, M., and Hari, P.: UV-induced NOy emissions from Scots pine: Could they originate from photolysis of deposited $\mathrm{HNO}_{3}$ ? , Atmos. Environ., 40, 6201-6213, 2006.

Ren, X., Harder, H., Martinez, M., Lesher, R. L., Oliger, A., Simpas, J. B., Brune, W. H., Schwab, J. J., Demerjian, K. L., He, Y., Zhou, X., and Gao, H.: $\mathrm{OH}$ and $\mathrm{HO}_{2}$ chemistry in the urban atmosphere of New York City, Atmos. Environ., 37, 3639-3651, 2003.

Ren, X., Brune, W. H., Mao, J., Mitchell, M. J., Lesher, R. L., Simpas, J. B., Metcalf, A. R., Schwab, J. J., Cai, C., Li, Y., Demerjian, K. L., Felton, H. D., Boynton, G., Adams, A., Perry, J., He, Y., Zhou, X., and Hou, J.: Behavior of $\mathrm{OH}$ and $\mathrm{HO}_{2}$ in the winter atmosphere in New York City, Atmos. Environ., 40, 252-263, 2006.

Rockne, K. J., Taghon, G. L., and Kosson, D. S.: Pore structure of soot deposits from several combustion sources, Chemosphere, 41, 1125-1135, 2000.

Rohrer, F., Bohn, B., Brauers, T., Brüning, D., Johnen, F.-J., Wahner, A., and Kleffmann, J.: Characterisation of the photolytic HONO-source in the atmosphere simulation chamber SAPHIR, Atmos. Chem. Phys., 5, 2189-2201, doi:10.5194/acp-5-21892005, 2005.

Sakamaki, F., Hatakeyama, S., and Akimoto, H.: Formation of nitrous acid and nitric oxide in the heterogeneous dark reaction of nitrogen dioxide and water vapour, Int. J. Chem. Kinet., 15, 1013-1029, 1983

Saliba, N. A., Yang, H., and Finlayson-Pitts, B. J.: Reaction of gaseous nitric oxide with nitric acid on silica surfaces in the presence of water at room temperature, J. Phys. Chem. A, 105, 10339-10346, 2001.

Sander, S. P., Friedl, R. R., Golden, D. M., Kurylo, M. J., Moortgat, G. K., Keller-Rudek, H., Wine, P. H., Ravishankara, A. R., Kolb, C. E., Molina, M. J., Finlayson-Pitts, B. J., Huie, R. E., and Orkin, V. L.: Chemical kinetics and photochemical data for use in atmospheric studies evaluation number 15, Jet Propulsion Laboratory, Pasadena, 523, 2006.

Sarwar, G., Pinder, R. W., Appel, K. W., Mathur, R., and Carlton, A. G.: Examination of the impact of photoexcited $\mathrm{NO}_{2}$ chemistry on regional air quality, Atmos. Environ., 43, 6383-6387, 2009.

Schmid, H. P.: Footprint modeling for vegetation atmosphere exchange studies: a review and perspective, Agr. Forest. Meteorol., 113, 159-183, 2002.

Sleiman, M., Gundel, L. A., Pankow, J. F., Jacob, P., Singer, B. C., and Destaillats, H.: Formation of carcinogens indoors by surfacemediated reactions of nicotine with nitrous acid, leading to potential thirdhand smoke hazards, P. Natl. Acad. Sci. USA, 107, 6576-6581, 2010.

Sörgel, M., Trebs, I., Serafimovich, A., Moravek, A., Held, A., and 
Zetzsch, C.: Simultaneous HONO measurements in and above a forest canopy: influence of turbulent exchange on mixing ratio differences, Atmos. Chem. Phys., 11, 841-855, doi:10.5194/acp11-841-2011, 2011.

Stemmler, K., Ammann, M., Donders, C., Kleffmann, J., and George, C.: Photosensitized reduction of nitrogen dioxide on humic acid as a source of nitrous acid, Nature, 440, 195-198, 2006.

Stemmler, K., Ndour, M., Elshorbany, Y., Kleffmann, J., D’Anna, B., George, C., Bohn, B., and Ammann, M.: Light induced conversion of nitrogen dioxide into nitrous acid on submicron humic acid aerosol, Atmos. Chem. Phys., 7, 4237-4248, doi:10.5194/acp-7-4237-2007, 2007.

Stull, R. B.: An introduction to boundary layer meteorology, Atmospheric and Oceanographic Sciences Library, Kluwer Academic Publishers, Dordrecht, 670 pp., 1988.

Stutz, J., Alicke, B., and Neftel, A.: Nitrous acid formation in the urban atmosphere: Gradient measurements of $\mathrm{NO}_{2}$ and HONO over grass in Milan, Italy, J. Geophys. Res., 107, 8192, doi:10.1029/2001JD000390, 2002.

Stutz, J., Alicke, B., Ackermann, R., Geyer, A., Wang, S., White, A. B., Williams, E. J., Spicer, C. W., and Fast, J. D.: Relative humidity dependence of HONO chemistry in urban areas, J. Geophys. Res., 109, D03307, doi:10.1029/2003JD004135, 2004.

Su, H., Cheng, Y. F., Cheng, P., Zhang, Y. H., Dong, S., Zeng, L. M., Wang, X., Slanina, J., Shao, M., and Wiedensohler, A.: Observation of nighttime nitrous acid (HONO) formation at a nonurban site during PRIDE-PRD2004 in China, Atmos. Environ., 42, 6219-6232, 2008a.

Su, H., Cheng, Y. F., Shao, M., Gao, D. F., Yu, Z. Y., Zeng, L. M., Slanina, J., Zhang, Y. H., and Wiedensohler, A.: Nitrous acid (HONO) and its daytime sources at a rural site during the 2004 PRIDE-PRD experiment in China, J. Geophys. Res., 113, D14312, doi:10.1029/2007JD009060, 2008b.

Su, H., Cheng,Y., Oswald, R., Behrendt, T., Trebs, I., Meixner, F.X., Andreae, M. O., Cheng, P., Zhang, Y., and Pöschl, U.: Soil Nitrite as a Source of Atmospheric HONO and OH Radicals, Science, 333, 1616-1618, doi:10.1126/science.1207687, 2011.

Svennsson, R., Ljungstrom, E., and Lindqvist, O.: Kinetics of the reaction between nitrogen dioxide and water vapour, Atmos. Environ., 21 1529-1539, 1987.

Trebs, I., Bohn, B., Ammann, C., Rummel, U., Blumthaler, M., Königstedt, R., Meixner, F. X., Fan, S., and Andreae, M. $\mathrm{O}$ : Relationship between the $\mathrm{NO}_{2}$ photolysis frequency and the solar global irradiance, Atmos. Meas. Tech., 2, 725-739, doi:10.5194/amt-2-725-2009, 2009.

Trick, S.: Formation of nitrous acid on urban surfaces - a physicalchemical perspective, Ph.D. thesis, University Heidelberg, Germany, 290 pp., 2004.

Veitel, H.: Vertical profiles of $\mathrm{NO}_{2}$ and $\mathrm{HONO}$ in the boundary layer, Ph.D. thesis, University, Heidelberg, Germany, 270 pp., 2002.

Vesala, T., Kljun, N., Rannik, Ü., Rinne, J., Sogachev, A., Markkanen, T., Sabelfeld, K., Foken, T., and Leclerc, M. Y.: Flux and concentration footprint modelling: State of the art, Environ. Pollut., 152, 653-666, 2008.
Vogel, B., Vogel, H., Kleffmann, J., and Kurtenbach, R.: Measured and simulated vertical profiles of nitrous acid - Part II. Model simulations and indications for a photolytic source, Atmos. Environ., 37, 2957-2966, 2003.

Wennberg, P. O. and Dabdub, D.: Rethinking ozone production, Science, 319, 1624-1625, 2008.

Wentzell, J. J. B., Schiller, C. L., and Harris, G. W.: Measurements of HONO during BAQS-Met, Atmos. Chem. Phys., 10, 12285 12293, doi:10.5194/acp-10-12285-2010, 2010.

Wong, K. W., Oh, H.-J., Lefer, B. L., Rappenglück, B., and Stutz, J.: Vertical profiles of nitrous acid in the nocturnal urban atmosphere of Houston, TX, Atmos. Chem. Phys., 11, 3595-3609, doi:10.5194/acp-11-3595-2011, 2011.

Yabushita, A., Enami, S., Sakamoto, Y., Kawasaki, M., Hoffmann, M. R., and Colussi, A. J.: Anion-catalyzed dissolution of $\mathrm{NO}_{2}$ on aqueous microdroplets, J. Phys. Chem. A, 113, 4844-4848, 2009.

Yu, Y., Galle, B., Panday, A., Hodson, E., Prinn, R., and Wang, S.: Observations of high rates of $\mathrm{NO}_{2}-\mathrm{HONO}$ conversion in the nocturnal atmospheric boundary layer in Kathmandu, Nepal, Atmos. Chem. Phys., 9, 6401-6415, doi:10.5194/acp-9-6401-2009, 2009.

Zhang, N., Zhou, X., Shepson, P. B., Gao, H., Alaghmand, M., and Stirm, B.: Aircraft measurement of HONO vertical profiles over a forested region, Geophys. Res. Lett., 36, L15820, doi:10.1029/2009GL038999, 2009.

Zhou, X., Civerolo, K., Dai, H., Huang, G., Schwab, J., and Demerjian, K.: Summertime nitrous acid chemistry in the atmospheric boundary layer at a rural site in New York State, J. Geophys. Res., 107, 4590, doi:10.1029/2001JD001539, 2002a.

Zhou, X., He, Y., Huang, G., Thornberry, T. D., Carroll, M. A., and Bertman, S. B.: Photochemical production of nitrous acid on glass sample manifold surface, Geophys. Res. Lett., 29, 1681, doi:10.1029/2002GL015080, 2002b.

Zhou, X., Gao, H., He, Y., Huang, G., Bertman, S. B., Civerolo, K., and Schwab, J.: Nitric acid photolysis on surfaces in low- $\mathrm{NO}_{\mathrm{X}}$ environments: Significant atmospheric implications, Geophys Res. Lett., 30, 2217, doi:10.1029/2003GL018620, 2003.

Zhou, X., Zhang, N., TerAvest, M., Tang , D., Hou, J., Bertman, S., Alaghmand, M., Shepson, P. B., Carroll, M. A., Griffith, S., Dusanter, S., and Stevens, P. S.: Nitric acid photolysis on forest canopy surface as a source for tropospheric nitrous acid, Nat. Geosci., 4, 440-443, doi:10.1038/ngeo1164, 2011.

Zhu, C., Xiang, B., Zhu, L., and Cole, R.: Determination of absorption cross sections of surface-adsorbed $\mathrm{HNO}_{3}$ in the $290-330 \mathrm{~nm}$ region by Brewster angle cavity ring-down spectroscopy, Chem. Phys. Lett., 458, 73-377, 2008.

Zhu, C., Xiang, B., Chu, L. T., and Zhu, L.: Photolysis of nitric acid in the gas phase, on aluminum surfaces, and on ice films, J. Phys. Chem. A, 114, 2561-2568, 2010. 